
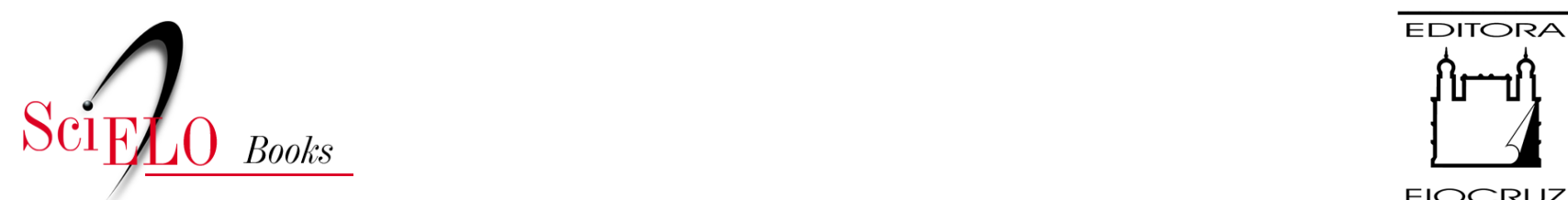

\title{
3. Gestão pública no Brasil do século XXI tendências reformistas e o desafio da profissionalização
}

\author{
Ricardo Carneiro
}

Flávia de Paula Duque Brasil

\section{SciELO Books / SciELO Livros / SciELO Libros}

CARNEIRO, R., and BRASIL, F.P.D. Gestão pública no Brasil do século XXI: tendências reformistas e o desafio da profissionalização. In: GADELHA, P., NORONHA, J.C., DAIN, S., and PEREIRA, T.R., eds. Brasil Saúde Amanhã: população, economia e gestão [online]. Rio de Janeiro: Editora FIOCRUZ, 2016, pp. 75-117. ISBN: 978-65-5708-093-1.

https://doi.org/10.7476/9786557080931.0005.

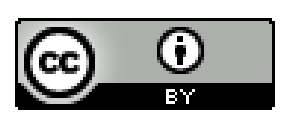

All the contents of this work, except where otherwise noted, is licensed under a Creative Commons Attribution 4.0 International license.

Todo o conteúdo deste trabalho, exceto quando houver ressalva, é publicado sob a licença Creative Commons Atribição 4.0.

Todo el contenido de esta obra, excepto donde se indique lo contrario, está bajo licencia de la licencia $\underline{\text { Creative }}$ Commons Reconocimento 4.0. 


\title{
GESTÃO PÚBLICA NO BRASIL DO SÉCULO XXI: TENDÊNCIAS REFORMISTAS E O DESAFIO DA PROFISSIONALIZAÇÃO
}

\author{
Ricardo Carneiro \\ Flávia de Paula Duque Brasil
}

Como prover bens e serviços de forma a satisfazer as necessidades básicas de consumo dos indivíduos, tendo em vista o incremento do bem-estar social? Tem-se aqui uma das questões mais centrais e, ao mesmo tempo, mais polêmicas da teoria e da prática política contemporâneas. Abordá-la requer considerações acerca das relações concretas que se estabelecem na sociedade quanto à apropriação e alocação dos recursos produtivos e à distribuição dos resultados alcançados, o que remete, por sua vez, às noções de Estado e mercado. Com lógicas de funcionamento distintas e portadores de resultados também distintos, a coexistência desses dois mecanismos alternativos de coordenação de interesses não escapa a uma permanente tensão, em que a competência de um frente ao outro é o que está em jogo.

Sem desconhecer os riscos de uma simplificação excessiva, é relativamente consensual que cabe ao poder público definir e legitimar objetivos e metas coletivas, o que envolve a padronização e distribuição de recursos, bem como o desenvolvimento e a manutenção de sistemas de controle burocrático, com implicações de natureza e intensidade variadas nas relações sociais e produtivas dos diversos campos de atividade. Fica claro, em tal proposição, o entrelaçamento da discussão do tema com "recomendações, valoração normativa e prescrições" (Vincent, 1987: 41), o que, evidentemente, limita qualquer pretensão de uma convergência interpretativa mais geral. A revivescência de um discurso aderente à lógica do mercado no contexto das últimas décadas do século $\mathrm{XX}$, em que o intervencionismo estatal nos campos econômico e social parecia constituir um fenômeno natural, e sua derrocada na transição para o século XXI reafirmam, na prática, que não há respostas definitivas para a questão.

Discussões consequentes relativas ao Estado, contudo, implicam considerações não apenas acerca das funções que desempenha, mas também da forma como se estrutura para fazer o que faz, ou o que se espera que faça. A esse respeito, cabe observar que o denominador comum dos movimentos de reforma do Estado é o desenho de arranjos organizacionais e mecanismos institucionais capazes de assegurar a melhoria de seu desempenho operacional e a efetividade na implementação das ações que compõem a agenda de governo. Aponta-se aqui na direção das reformas na gestão pública, que ganharam particular saliência, no plano internacional, com o reformismo gerencial identificado à New Public Management (NPM), cuja emergência pode ser associada à hegemonia conquistada pelo pensamento neoliberal no decorrer dos anos 1970. 
Balizado por essas considerações gerais, busca-se examinar as reformas na gestão pública do Brasil no período contemporâneo, com destaque para as principais tendências reformistas que se desenrolam no século XXI. Para tanto, faz-se, inicialmente, uma breve incursão na literatura sobre a natureza das reformas processadas na gestão pública no plano internacional, dirigindo-se a atenção, na sequência, para a abordagem da trajetória percorrida por tais reformas no plano nacional. O passo seguinte consiste na análise, um pouco mais detida, das reformas que ganham corpo no país desde os anos 1990, aglutinadas em torno de três eixos principais: a desconcentração administrativa e o hibridismo advindo dos novos arranjos organizacionais; a descentralização político-administrativa e a crescente saliência dos governos locais; e a governança democrática, colocando em relevo as instituições participativas. A parte final é dedicada à discussão do desafio, ainda em aberto, referente à profissionalização da administração pública brasileira, considerando, entre outras dinâmicas, os próprios processos de reforma do Estado, bem como a perspectiva do aprofundamento democrático.

\section{Sobre as Reformas na Gestão Pública}

Esta seção procura situar, analiticamente, as transformações processadas na gestão pública como uma dimensão do movimento mais amplo de reforma do Estado. Destaca-se, na primeira parte, a ocorrência de determinadas ondas reformistas da administração pública, tipificadas pela implantação das reformas que gravitam em torno do modelo burocrático weberiano e, mais recentemente, pelo reformismo da NPM. Na segunda parte, examina-se a inserção do país nessas ondas reformistas, enfatizando-se as convergências e divergências em face do que se passa no plano internacional.

\section{As principais ondas reformistas e as tendências contemporâneas}

Reformas na administração pública constituem um fenômeno intrínseco à própria natureza do Estado, cujas funções tendem a se alterar ao longo do tempo, com implicações conexas sobre sua estrutura organizacional e a forma como esta opera. No entanto, as iniciativas reformistas não se prendem estritamente a razões de adequação da capacidade operacional às cambiantes funções desempenhadas pelo poder estatal. Ao contrário, uma ideia força que impulsiona ou justifica o reformismo é a intenção declarada de aprimorar o funcionamento do setor público (Kettl, 2005). Os fins visados por tal aprimoramento são os mais variados, incluindo desde a redução do gasto público à melhoria na qualidade dos serviços públicos prestados à população, passando por argumentos relacionados ao incremento da eficiência e da efetividade da ação governamental.

De um modo geral, os esquemas de reforma não tendem a ser abrangentes, mesmo em suas intenções. Conforme Pollitt e Bouckaert (2004: 26), os reformistas buscam "aprimorar uma instituição ou um programa, ou, às vezes, um setor inteiro (saúde, educação), mas raramente remodelar o conjunto das instituições do setor público de uma vez". Algumas poucas reformas do setor público assumem uma configuração mais abrangente, em termos de escopo e de abrangência espacial. Isto permite falar, como o fazem Christensen e Laegreid (2012), da existência de ondas reformistas, traduzindo um conjunto de iniciativas de mudanças na estrutura, processos e práticas das organizações que compõem a administração pública, informadas por pressupostos similares e movidas por razões 
também similares, que se disseminam por um número expressivo de países, com destaque para aqueles de maior grau de desenvolvimento. No entanto, ainda que diferentes países se envolvam numa determinada onda reformista, a reforma da administração pública, como salienta Lynn Jr. (2007: 46), configura-se como uma "questão primariamente nacional", refletindo a influência de uma série de fatores, dentre os quais as características do sistema político, com suas configurações próprias e "padrões regulares de ação e decisão" (Lima Jr., 1998: 21), que podem facilitar ou restringir sua implementação (Pollitt \& Bouckaert, 2004).

As ondas reformistas a que se referem Christensen e Laegreid (2012) não implicam transformações abruptas na organização do setor público e em seu modus operandi. Ao contrário, o que se tem é um processo gradual de mudanças, tornando até mesmo difícil "identificar o fim de uma onda reformista e o começo de outra" (Christensen \& Laegreid, 2012: 262). Como mostra o caso americano, examinado por March e Olsen (1989), as mudanças mais efetivas e duradoras na administração pública do país ocorreram de forma gradativa, numa dinâmica em que os intentos reformistas frequentemente não se materializam ou apresentam resultados muito aquém do pretendido.

O que motiva ou desencadeia uma onda reformista é a percepção de problemas no funcionamento do setor público, sejam eles relacionados a questões de coordenação e controle das organizações que o compõem ou a deficiências em capacidade operacional de prover bens e serviços à população. Essa percepção pode ser influenciada, e na prática o é, por ideias e pressões de origem variada, além de mostrar-se suscetível a revisões ao longo da implementação das iniciativas reformistas que, como visto, caracterizam-se pelo gradualismo, abrindo espaço para frequentes correções de rumo ou mesmo a retroação. Dessa dinâmica reformista não resulta, como argumentam Christensen e Laegreid (2012), uma ruptura com o sistema político-administrativo existente, mas sua remodelação. Há, na interpretação dos autores, uma articulação entre o novo modelo proposto e aquele existente, produzindo um sistema administrativo híbrido, em que se combinam elementos trazidos pelas reformas com elementos tradicionais da arquitetura do sistema anterior. Tal articulação pode ser vista como um processo de sedimentação, no sentido de que novas reformas vão se adicionando a reformas pretéritas, com a coexistência de elementos originários de distintas eras ou ondas reformistas.

Uma das ondas reformistas mais marcantes da sociedade moderna é aquela que resultou na denominada "administração pública progressiva", cuja emergência remete às décadas finais do século XIX (Hood, 1995). Como mostra ampla literatura, ${ }^{1}$ esse movimento reformista, que converge para a adoção do modelo burocrático weberiano, busca lidar com problemas relacionados à corrupção e ao uso abusivo do poder político, de um lado, e à incompetência operacional e ao desperdício de recursos públicos que a acompanha, de outro.

Outra importante onda reformista começa a tomar forma no último quartel do século passado. Trata-se das iniciativas congregadas sob o rótulo da NPM. Tal movimento faz contraponto à administração burocrática weberiana, traduzindo formalmente a preocupação com a melhoria no desempenho do setor público, notadamente no que se refere à prestação de serviços públicos à sociedade. Para

\footnotetext{
${ }^{1}$ Ver, a esse respeito, Carneiro e Menicucci (2011).
} 
lidar com os problemas atribuídos à burocracia, a NPM propõe uma série de iniciativas reformistas, de natureza variada, que procura imprimir maior agilidade, responsividade e eficiência à administração pública (Hood, 1991, 1995; Manning et al., 2009; Carneiro \& Menicucci, 2011).

Tais iniciativas são agrupadas por Dunleavy e colaboradores (2005) em torno de três eixos principais, descritos pelos autores como desagregação, competição e sistemas de incentivos econômicos inspirados na dinâmica de mercado. Dentre os componentes mais usuais ou recorrentes dos mencionados eixos, incluem-se elementos como: agencificação, descentralização inter e intragovernamental, terceirização e parcerias com empresas e organizações não governamentais. Gestados e postos em prática nos países anglo-saxões, os experimentos reformistas afinados com a NPM difundem-se pelos diversos países desenvolvidos a partir dos anos 1980, alcançando, na sequência, países em desenvolvimento, notadamente da América Latina.

Desde os anos finais do século passado, contudo, começam a se evidenciar os sinais de esgotamento do reformismo da NPM (Carneiro \& Menicucci, 2011), que se tornam mais nítidos a partir da transição para o século XXI. Tal esgotamento aparece associado não só ao fato de as reformas empreendidas apresentarem resultados aquém do prometido, em termos da melhoria do desempenho da administração pública, mas também à percepção do fato de elas serem portadoras de consequências não pretendidas, com destaque para a fragmentação ou desintegração sistêmica, suscitando crescentes problemas de coordenação e controle na implementação das políticas públicas (Pollitt \& Bouckaert, 2004; Hood \& Peters, 2004, Dunleavy et al., 2005; Christensen \& Laegreid, 2012). No rastro desse processo, a NPM começa a ser suplementada por outras iniciativas mudancistas, originando uma nova onda de reformas, designada por Christensen e Laegreid (2012) como pós NPM. São ações endereçadas a lidar com os problemas derivados da adoção das recomendações e práticas da NPM, o que significa esforços com vistas a restabelecer uma situação de maior "integração, coordenação e capacidade" (Christensen \& Laegreid, 2007: 1.060) de atuação no setor público.

Esse quadro coloca em relevo conceitos como governança e accountability, ao lado do papel do governo central (Carneiro \& Menicucci, 2011). Trata-se do reconhecimento da necessidade de introduzir mudanças na forma como o governo atua, tendo em vista a crescente complexidade das ações de coordenação e controle advindas tanto da multiplicação das parcerias com atores da sociedade civil e do mercado, quanto da intensificação da heterogeneidade interna ao aparato público, no que se refere às estruturas, funções e interesses das organizações que o compõem. Em complemento, há o reconhecimento, por parte de uma literatura mais crítica, de que reformas da administração pública não podem ser vistas apenas como uma questão de natureza técnica, mas fundamentalmente como uma questão política (Christensen \& Laegreid, 2007; Bourgon, 2010; Carneiro \& Menicucci, 2011). E como uma questão política ela implica o compromisso com o aprofundamento democrático, consoante as premissas de um governo aberto e inclusivo. Para tanto, é indispensável uma burocracia não apenas profissionalizada, mas de perfil distinto, que alie capacidade técnica a capacidade política, tendo em perspectiva uma interlocução mais estreita e profícua com a sociedade, de modo a favorecer ações que sejam mais coerentes e aderentes à ideia de uma cidadania ativa (Carneiro \& Menicucci, 2011). 
A maneira como os diferentes países se engajam nas ondas reformistas, bem como o conteúdo e o percurso das reformas neles ocorridas, apresentam conformação muito variada. Isto não surpreende na medida que as condições internas de cada país, no que diz respeito às variáveis que influenciam as escolhas relativas ao tipo de reforma a adotar e a viabilidade de sua implementação, em que se destacam as características de seus sistemas político-administrativos, são muito distintas. O que se tem é uma típica dependência de trajetória, com pontos de partida não apenas diferentes, mas que se alteram de forma também desigual ao longo do tempo. É o que ocorre, em particular, no Brasil, que sequer conseguiu implantar uma administração pública burocrática, profissionalizada e meritocrática, a despeito de tal propósito ser reiterado nos textos constitucionais promulgados ao longo do século XX. E que adere ao reformismo gerencial no âmbito de uma agenda política que preconiza o ajuste fiscal como suporte à estabilização monetária, ou seja, por razões macroeconômicas e não propriamente administrativas.

\section{A inserção brasileira nas reformas da gestão pública}

A adesão do Brasil aos movimentos reformistas internacionais é tardia, uma vez que o país não se colocou na vanguarda das reformas, incorporando-se às mesmas com relativa defasagem temporal. Isso se aplica tanto à construção da administração burocrática clássica quanto à adoção do reformismo associado à NPM. A exceção se manifesta nas tendências que se seguem às reformas da NPM, com destaque para a temática da governança democrática, cuja entrada na agenda pública brasileira é contemporânea ao que se passa no plano internacional.

Ao caráter tardio se soma uma relativa frouxidão na implementação das ações reformistas, que assumem caráter parcial ou inconcluso, na linha daquilo que Rezende (2002) designa como falha sequencial. Observam-se também enormes desigualdades federativas no encaminhamento das ações reformistas e em seus resultados, seja sob a ótica vertical - os diferentes níveis de governo - seja horizontal - os governos estaduais e os locais. Tal fato em nada surpreende, dada a heterogeneidade que marca a realidade brasileira em suas várias dimensões, especialmente na dimensão políticoadministrativa. Na perspectiva vertical, os avanços mais expressivos tendem a se dar no âmbito do governo federal; na perspectiva horizontal, os principais avanços indicam a direção dos governos estaduais e locais das regiões mais ricas ou desenvolvidas.

A primeira onda de reformas da administração pública, fundada na adoção das premissas do modelo burocrático weberiano, chega ao Brasil com relativo atraso, comparativamente aos países que compõem o núcleo central do capitalismo ocidental. Introduzida nas principais nações europeias ainda no século XIX e nos Estados Unidos no início do século XX (Bresser-Pereira, 1996), a concepção clássica de burocracia só começa a ganhar corpo na agenda pública brasileira no decorrer da década de 1930, com a ascensão de Getúlio Vargas ao poder. Tem-se então um processo de centralização política, racionalização e modernização administrativa, que se articula em torno do propósito de industrialização liderada pelo Estado. Tal propósito "depende, nitidamente, da criação de meios apropriados para financiar, subsidiar, controlar e supervisionar" as políticas públicas formuladas em prol da promoção do desenvolvimento econômico (Nunes, 1997: 56). Sua materialização envolve, de um lado, a implantação de estatutos normativos e órgãos normativos fiscalizadores e, de outro, a estruturação de um aparato administrativo profissionalizado e meritocrático. 
O esforço reformista empreendido no período fica emblematizado na criação, em 1938, do Departamento de Administração do Serviço Público (Dasp), ao qual cabia a responsabilidade de definir, racionalizar e controlar a carreira do funcionalismo público, bem como de organizar a estrutura administrativa do governo federal. Em cumprimento às suas atribuições, o órgão definiu normas e regras de admissão e recrutamento de pessoal para o serviço público, baseado no sistema de mérito e na realização de concursos públicos, competitivos e obrigatórios - princípios fundamentais de uma burocracia profissionalizada, de conformação weberiana. No entanto, sua ação não deixou de ser limitada, refletindo a necessidade do uso da máquina pública para fins de obtenção de apoio político.

Trata-se de uma espécie de vício de origem, que cerceia as possibilidades de se implantar no país um serviço público profissionalizado, de aplicação universal. De fato, desde a Constituição Federal de 1934, quando se introduziu o concurso público como regra geral para acesso aos cargos públicos, todos os textos constitucionais brasileiros, ao mesmo tempo que reafirmam o compromisso com a profissionalização, abrem brechas ${ }^{2}$ que se contrapõem "ao espírito da burocracia racional-legal" (Lima Jr., 1998: 28). Na práxis administrativa, a convivência de uma burocracia profissionalizada com práticas políticas arcaicas, no sentido de pré-burocráticas, se faz por meio da solução designada por Nunes (1997) como "insulamento burocrático".

O recurso à administração paralela é consagrado pelo decreto-lei n. 200, editado em 1967. Esse documento patrocinou o espraiamento da administração indireta pelas áreas que interessavam à agenda pública, notadamente aquelas mais diretamente vinculadas à promoção do desenvolvimento econômico. Ao lado disso, "as áreas que estavam fora do campo das prioridades ficavam na administração direta, que quase sempre funcionava com uma burocracia ineficiente, por conta de fatores como a patronagem, o cartorialismo e a falta de incentivos à profissionalização" (Abrucio, Pedroti \& Pó, 2010: 49-50).

A contratação de pessoal, nos termos da Consolidação das Leis do Trabalho (CLT), passa a ser utilizada para o preenchimento de cargos na administração direta, o que, na prática, significa a "dispensa do uso do concurso como mecanismo de entrada no serviço público" (Carvalho, 2011: 57). Dessa conduta resulta um aparato estatal composto por uma multiplicidade de "corpos administrativos, com formas de legitimidade e meritocracia diferentes e sem diálogo entre si, inviabilizando uma efetiva gestão de pessoal" (Abrucio, Pedroti \& Pó, 2010: 52).

Um novo ensaio de implantação de uma burocracia informada pelas premissas do modelo weberiano se dá com a promulgação da Constituição Federal (CF) de 1988 (Brasil, 2006), que dedica um capítulo específico ao tema da administração pública. Dentre as medidas introduzidas, incluem-se a adoção do princípio do concurso público, universalizado como forma de recrutamento de pessoal para o serviço público, e a previsão de planos de carreira, conjugando estabilidade e perspectiva

\footnotetext{
${ }^{2}$ Para fins de ilustração, a Constituição Federal de 1946 prescreve, no artigo 23 de suas disposições transitórias, que "os atuais funcionários interinos da União, dos Estados e Municípios, que contem com pelo menos cinco anos de exercício, serão automaticamente efetivados na data de promulgação deste Ato; e os atuais extranumerários, que exerçam função de caráter permanente há mais de cinco anos (...) serão equiparados aos funcionários para efeitos de estabilidade, aposentadoria, licença, disponibilidade e férias" (Brasil, 2014a). Algo similar se passa com os textos constitucionais posteriores, inclusive o de 1988.
} 
de progressão a longo prazo. Igualmente importante, estabelece-se o Regime Jurídico Único (RJU) nas administrações direta e indireta, rompendo com a diversidade de contratações no setor público vigente à época.

No entanto, como vários dispositivos constitucionais, a natureza do regime que passaria a vigorar não foi especificada no texto constitucional, sendo remetida para legislação posterior. Tal definição vai se dar por meio da lei n 8.112/1990, com a opção pelo regime de direito estatutário ou público. Essa normatização afeta particularmente as fundações e autarquias, que passam a se assemelhar à administração direta. E, a mesma lei, reproduzindo práticas presentes nas mudanças constitucionais anteriores, permite a transformação dos servidores civis em estatutários, fragilizando o propósito de restringir o recrutamento à realização de concurso. ${ }^{3}$

Decorrida uma década, o texto constitucional foi modificado por força da emenda constitucional n. 19/1998, cujo conteúdo reflete proposições feitas no Plano Diretor da Reforma do Aparelho do Estado (PDRAE), que, como se verá mais à frente, expressa a principal referência para a reforma de cunho gerencial idealizada pelo governo Fernando Henrique Cardoso. Das diversas alterações introduzidas pela emenda, uma das mais relevantes refere-se ao RJU, que passou a ficar restrito às denominadas funções exclusivas ou típicas do Estado. ${ }^{4} \mathrm{Em}$ conexão com essa mudança, houve a flexibilização da exigência de realização de concurso público para fins de recrutamento de pessoal, atrelando-a basicamente à investidura em cargo ou emprego público. Outra medida guarda relação com a estabilidade do servidor, também flexibilizada, "passando a ser justificada a demissão por insuficiência de desempenho" (Carvalho, 2011: 76). Por fim, foram introduzidos parâmetros de restrição orçamentária, que serão regulamentados pela lei complementar n. 101/2000 - conhecida como Lei de Responsabilidade Fiscal (LRF) -, que vincula os gastos com servidores ativos e inativos do setor público à gestão fiscal.

A administração pública brasileira adentra o século XXI sem alcançar a desejável e necessária profissionalização do servidor público, a despeito do fortalecimento e expansão, nos anos mais recentes, do sistema de mérito. Vale dizer, não se institucionalizou, no país, a organização do tipo weberiano, o que se evidencia, com maior nitidez, nos níveis subnacionais de governo.

Como as reformas burocráticas, a onda reformista da NPM também alcança o país com relativo atraso, em comparação com a sua emergência e disseminação no plano internacional. O marco do processo remete à criação, no início do primeiro mandato do governo Fernando Henrique Cardoso, do Ministério da Administração e Reforma do Estado (Mare), cuja proposta reformista ganha contornos formais com a edição, em 1995, do já mencionado PDRAE. Reproduzindo o diagnóstico que embasa o reformismo da NPM, o PDRAE parte de uma crítica à burocracia e, por extensão, à CF 1988, que teria, nos termos do documento, levado a "um retrocesso burocrático sem precedentes" (Brasil, 1995: 20). O alvo principal da crítica consiste no fato de a CF 1988 retirar, da administra-

\footnotetext{
${ }^{3}$ Para fins de ilustração, no âmbito do governo federal, de acordo com Marconi (2010), todos os servidores celetistas, com exceção daqueles vinculados às estatais, tornaram-se estatutários, o que envolveu cerca de 400 mil pessoas.

${ }^{4}$ Enquadram-se nessa categoria as carreiras relacionadas às atividades de defesa nacional, arrecadação tributária, "fiscalização, diplomacia, formulação de políticas públicas, elaboração e execução orçamentária e regulação" (Marconi, 2010: 231), além de segurança pública, nos níveis federal e estadual.
} 
ção indireta, a flexibilidade operacional de que esta dispunha desde a edição do decreto-lei n. 200, "ao atribuir às fundações e autarquias públicas normas de funcionamento idênticas às que regem a administração direta" (Brasil, 1995: 20).

A concepção mais geral da proposta reformista do Mare é informada pelas reformas econômicas de cunho neoliberal em curso no período. ${ }^{5}$ Refletindo essa sintonia, o PDRAE parte de uma demarcação das relações entre Estado e mercado, utilizando-a para especificar as áreas que seriam próprias do Estado ou nas quais sua atuação se justificaria, ${ }^{6}$ bem como as respectivas formas de propriedade e de gestão (Bresser-Pereira, 1996; Lima Jr., 1998). Dessa demarcação resulta a proposição de quatro setores para a atuação estatal, designadas como núcleo estratégico, atividades exclusivas, atividades ou serviços não exclusivos e área de produção de bens e serviços para o mercado (Bresser-Pereira, 1996). Com base em tal distinção, o PDRAE propõe um redesenho organizacional do aparato estatal, considerando formas de propriedade e de gestão, que se orienta na direção da desconcentração administrativa, inspirada no reformismo gerencial da Inglaterra.

Para as atividades estratégicas, o PDRAE reafirma o modelo burocrático weberiano, que ficaria estruturado, assim, em torno das carreiras típicas de Estado. Para as atividades referentes à produção de bens e serviços para o mercado, aponta-se para a privatização, consoante a lógica neoliberal, de precedência do mercado em relação ao Estado no tocante a alocações de recursos na economia, ficando a cargo de empresas estatais, a rigor, aquelas que não pudessem ser administradas privadamente (Bresser-Pereira, 1996). As principais inovações dizem respeito às atividades exclusivas e aos serviços não exclusivos. Para elas, o desejável, do ponto de vista do PDRAE, seria a flexibilidade operacional que a administração indireta dispunha anteriormente à promulgação da CF 1988, consoante o espírito do decreto-lei n. 200/1967.

A solução proposta consistiu na criação de duas novas formas organizacionais: a agência autônoma e a organização social (OS). Ambas seriam revestidas de maior autonomia administrativa e financeira, em face das normas de funcionamento impostas pela CF 1988 às administrações direta e indireta. A agência autônoma corresponde ao modelo organizacional delineado para os órgãos e entidades vinculadas às atividades exclusivas, enquanto a OS corresponde ao modelo aplicável às atividades ou serviços não exclusivos do Estado. Embora não mencionado no PDRAE, o governo federal introduziu, quase à mesma época da regulamentação das OSs, um novo arranjo capaz de assumir funções relacionadas aos serviços não exclusivos, designado como Organização da Sociedade Civil de Interesse Público (Oscip). Tal formato conflui formalmente para o propósito de ampliar o compartilhamento da prestação de serviços públicos com organizações não governamentais.

O reformismo gerencial preconizado pelo PDRAE teve fôlego curto, o que se evidencia na extinção do Mare no segundo mandato de Fernando Henrique Cardoso. Dos novos arranjos organizacionais propostos, pouca coisa saiu do plano das intenções, o que se aplica tanto às agências executivas quanto às OSs. Os avanços mais expressivos ocorreram na área da produção de bens e serviços para

\footnotetext{
${ }^{5}$ Iniciada no governo Collor, a agenda de reformas neoliberais se aprofunda no governo Fernando Henrique Cardoso.

${ }^{6}$ A referência mais geral para tal demarcação remete às denominadas falhas de mercado, consoante as premissas analíticas da economia neoclássica.
} 
o mercado, com a privatização de diversas empresas estatais. Essa mesma ênfase na privatização impulsionou a criação de agências reguladoras, que expressam, ao lado das agências executivas, um dos formatos institucionais das agências autônomas, ainda que apenas brevemente mencionado no texto do Plano Diretor (Torres, 2007).

À paralisia das reformas gerenciais na esfera do governo federal, associam-se avanços no âmbito dos governos subnacionais, em especial dos estados. É o que se observa no tocante às proposições referentes aos novos formatos organizacionais aplicáveis às atividades não exclusivas do Estado, representados pelas OSs e Oscips. Como argumentam Abrucio, Pedroti e Pó (2010: 61), "tais formas deram mais certo nos estados que na União".

Mais recentemente, o país adere ao mecanismo da parceria público-privada (PPP), que se difunde no plano internacional, desde a década de 1990, como um novo arranjo institucional aplicado à realização de investimentos em infraestrutura ou à provisão de um serviço público. Embora não prevista na arquitetura do PDRAE, a PPP se coaduna com sua concepção mais geral, alargando o espaço de atuação da iniciativa privada tanto na área de serviços não exclusivos quanto na de serviços para o mercado.

Ao lado dos ensaios feitos a fim de adotar arranjos organizacionais e instrumentos que confluem para as proposições reformistas da NPM, há, desde meados dos anos 1990, um notável avanço na direção da descentralização, notadamente no campo das políticas sociais, que não pode ser visto ou interpretado como decorrência de uma adesão ao paradigma gerencialista. O que se tem é um movimento conectado a um viés mais político, remetendo aos potenciais democratizantes e de aprofundamento democrático da gestão pública, em sintonia com os princípios orientadores e as diretrizes da CF 1988, que consagra o município como ente federado.

No caso dos países desenvolvidos, o impulso decisivo à descentralização é dado pela busca da melhoria de desempenho na provisão de serviços públicos à população, o que envolve processos mais próximos da noção de desconcentração, como a terceirização, a agencificação e as parcerias com o mercado e entidades da sociedade civil, dentre outros. No caso brasileiro, seguindo a trilha do que se observa na América Latina, a descentralização se faz no âmbito do movimento de redemocratização da vida política, o que lhe confere uma conotação distinta, de transferência de poder do nível central para os níveis subnacionais de governo. Trata-se, portanto, de um processo de descentralização política e administrativa, cujo foco é a prestação de serviços no campo social, definida como de competência comum ou partilhada no texto constitucional.

Outro movimento reformista de relevo no país guarda relação com a noção de governança, que começa a ser crescentemente empregada e difundida, desde os anos 1990, em temáticas relativas à gestão pública no plano internacional. Como observam diversos autores (Carneiro \& Menicucci, 2011; Christensen \& Laegreid, 2012; Klinj, 2012), a governança comparece às discussões críticas com o foco na NPM como um contraponto ou, distintamente, como um complemento às reformas administrativas - nesse caso, como uma forma de lidar com as consequências não pretendidas das reformas e como resposta às suas deficiências, com destaque para os déficits de inclusividade democrática. Assim, na literatura dos países centrais, a perspectiva de governança entremeia-se nos 
debates em torno das reformas da administração pública, na linha da NPM, sobretudo em virtude de seus desacertos e deficiências, e crescentemente abarca as possibilidades de participação democrática ou o viés participativo.

No caso brasileiro, e também no cenário de outros países latino-americanos, pode ser indicado um percurso distinto nas abordagens e práticas. No bojo da terceira onda de democratização, ocorrem expressivos processos de mobilização da sociedade civil, que se organiza de diversas formas, com plataformas de cunho democratizante e includente, voltadas para a descentralização, a ampliação de direitos sociais e a democratização das relações do Estado com a sociedade, por meio de mecanismos e de instâncias institucionais de participação. Tais agendas e propostas de reforma, seja no âmbito mais geral ou nos campos setoriais de políticas públicas, cunharam avanços no texto da CF 1988 e, nas décadas que se seguiram, modelaram inovações institucionais. No âmbito legal, a legislação das políticas sociais nos anos 1990 encampou a participação via conselhos como requisito obrigatório para repasse de recursos por meio de fundos, e na década seguinte, a legislação referente às políticas urbanas introduziu, de formas distintas, dispositivos relativos à participação.

A partir do final da década de 1980, os governos locais, de início aqueles de orientação política progressista ou democrático-populares, avançaram na criação de instituições participativas, como conselhos, orçamentos participativos, conferências municipais, arranjos participativos, na elaboração de planos diretores e correlatos, dentre outros desenhos mais específicos. No decurso das décadas seguintes, tais práticas afirmaram-se como tendência consolidada, observando-se a pluralidade e a multiplicação dessas instituições no âmbito local (Brasil \& Carneiro, 2010).

\section{Tendências Reformistas na Gestão Pública Brasileira do Século XXI}

Discutem-se a seguir as principais transformações em curso na administração pública brasileira, que, como visto na seção anterior, se articulam em torno de três eixos principais: a desconcentração intra e extragovernamental, a descentralização político-administrativa e a governança democrática. A abordagem relativa a cada eixo parte de uma rápida revisão teórica que informa a análise propriamente dita da temática em questão, na qual são feitas considerações acerca da trajetória percorrida e suas perspectivas de evolução num horizonte temporal de médio a longo prazo.

\section{Desconcentração extra e intragovernamental: novos arranjos organizacionais e hibridismo}

O movimento de reforma do Estado desencadeado nos anos 1970, com a ascensão do pensamento neoliberal, abriu espaço para uma maior penetração de agentes privados e de organizações não governamentais em áreas de atuação anteriormente de responsabilidade do setor público. Essa dinâmica é amplificada pelo reformismo da NPM, que se mobiliza, formalmente, em torno da melhoria da eficiência gerencial na provisão de bens e serviços à população (Dunleavy \& Hood, 1994; Manning et al., 2009; Pierre, 2009). Sob a influência da NPM, "os governos veem-se pressionados a cortar custos e ser mais responsivos e flexíveis na provisão de serviços" (Smith, 2007:591). Do processo 
resulta a proliferação de diferentes arranjos do setor público com organizações não governamentais e entes privados, implicando crescente hibridismo organizacional (Carneiro \& Menicucci, 2011).

Os novos arranjos postos em cena pela NPM vêm no rastro da intensificação da delegação da gestão de atividades de interesse público ou de competência da administração pública, mediante contratação, a um agente não estatal - empresa privada ou organização não governamental. Agrupadas sob o rótulo genérico de parceria, vão ser encontradas diversas formas de relação entre o setor público e entidades não estatais (Skelcher, 2007), que confluem para as noções de contracting out, out sourcing e joint venture, embora não se reduzam a elas.

Tais noções, convencionalmente associadas à terceirização, envolvem a "separação entre o comprador de um serviço e seu fornecedor" (Skelcher, 2007: 371). Nessa relação, a administração pública, na condição de comprador, fica com a responsabilidade pela especificação das características e condições de fruição do serviço, mas não por sua produção propriamente dita, cujo fornecimento é contratado a uma empresa privada ou organização não governamental. A natureza do serviço passível de ser adquirido é vasta, num arco que vai de atividades de provisão continuada pela administração pública, como coleta e disposição final de lixo, a atividades que se inscrevem no âmbito de uma dada política pública, como atendimento especializado a grupos mais vulneráveis da população (Skelcher, 2007).

As motivações para a realização desse tipo de parceria são variadas, dependendo não apenas da natureza do serviço contratado como do contexto político e cultural em que ocorre (Pollitt \& Bouckaert, 2002; Skelcher, 2007). A motivação mais recorrente listada na literatura é a busca pela redução de custos e ganhos de eficiência e qualidade na prestação do serviço público (Skelcher, 2007; Smith, 2007). Isto se fundamenta na presumida expertise do agente privado, o que também se aplica às organizações não governamentais, proporcionando ganhos de eficiência e inovação associados à especialização e ao melhor aproveitamento de ganhos de escopo e de escala. Além desse aspecto, interfere também no processo a maior autonomia decisória dos entes não estatais vis-à-vis a administração pública, no tocante às imposições de cunho institucional, que favorece a adoção de soluções, procedimentos e condutas mais ágeis e de menor custo. Menos frequentes, outras motivações guardam relação com os propósitos de contenção do tamanho da força de trabalho do setor público e de redução de suas responsabilidades diretas no gerenciamento da prestação do serviço.

Os limites ou potenciais problemas associados à terceirização remetem, de certa forma, a um exame mais criterioso das presumidas vantagens que revestem este tipo de parceria. A contratação pode, de fato, levar a operações mais eficientes, em termos técnicos e econômicos, mas, cabe observar, eficiência econômica não significa, necessariamente, que as operações sejam as mais adequadas às necessidades e opções do público interessado no serviço ou da sociedade como um todo. A chave para o sucesso da contratação consiste na definição criteriosa dos padrões de qualidade do serviço a ser prestado, o que nada tem de trivial, e na efetiva monitoria de sua prestação por parte da administração pública. Outro aspecto a ser observado diz respeito à existência de empresas ou organizações não governamentais com comprovada experiência e capacidade de atuação nos serviços que o governo deseja contratar, o que não necessariamente ocorre. No caso 
das organizações não governamentais, estas revelam-se "tipicamente subcapitalizadas", apresentando problemas com fluxo de caixa e capacidade de investir adequadamente em infraestrutura e força de trabalho profissionalizada (Smith, 2007: 596).

A noção de joint venture, por sua vez, remete a formas de cooperação entre o setor público e empresas privadas, tendo em vista o financiamento, a construção, a gestão ou manutenção de uma dada infraestrutura ou a prestação de um serviço (Comissão das Comunidades Europeias, 2004). São relações que se distinguem e se somam a instrumentos tradicionais de delegação da execução de funções ou atividades de interesse público a agentes do mercado, como a concessão e outras formas de descentralização extragovernamental. A lógica do processo requer a promoção de um projeto conjunto, em que as partes envolvidas mantêm sua coordenação como atores independentes, com escopo e repartição de responsabilidades bem definidos.

O gerenciamento desse tipo de relação contratual pode ser feito por meio de um acordo de parceria ou pela constituição de uma sociedade de fins específicos (Skelcher, 2007). As joint ventures são referidas como parcerias público-privadas (PPPs) no contexto europeu, onde emergem a partir da iniciativa pioneira do Reino Unido, com base na denominada Private Finance Iniciative, direcionada a viabilizar projetos de investimento público e a provisão de serviços a eles associados - iniciativa posteriormente relançada e renomeada como Public Private Partnership (PPP) (Brito \& Silveira, 2005). Sob esse rótulo genérico, as PPPs se difundem por vários países, com concepções distintas, informadas pelos respectivos marcos regulatórios. No Brasil, o modelo adotado emprega a terminologia PPP para expressar uma "forma de provisão de infraestruturas e serviços públicos em que o parceiro privado é responsável pela elaboração do projeto, financiamento, construção e operação de ativos, que são posteriormente transferidos ao Estado" (Brito \& Silveira, 2005: 8).

As motivações para a celebração de PPPs envolvem, como no caso da terceirização, a expectativa de que os serviços prestados pelo ente privado, empresa ou consórcio, possam ser desempenhados com maior eficiência econômica e qualidade (Comissão das Comunidades Europeias, 2004; Skelcher, 2007). Um dos principais argumentos embasando tal expectativa se ancora na possibilidade de integrar a elaboração do projeto executivo, sua construção e operação em um mesmo agente, gerando incentivos "não apenas à otimização dos custos com base no ciclo de vida do projeto" (Brito \& Silveira, 2005: 10), mas também a melhorias na qualidade do serviço prestado.

A agilização da implantação do investimento, potencializada pela definição de mecanismos de pagamento ao ente privado atrelados à disponibilidade do serviço, capazes de estimular o interesse por reduções no cronograma da obra, constitui outro benefício da PPP. Para além dos argumentos que focam ganhos de eficiência e qualidade, o debate referente às PPPs é perpassado pela questão do financiamento (Comissão das Comunidades Europeias, 2004). O argumento aqui remete à obtenção de espaço orçamentário para a realização de investimentos pelo setor público, o que ganha particular relevância em um quadro de restrições fiscais impondo limites ao endividamento. A parceria abre a possibilidade de diluir no tempo o aporte de recursos do setor público no projeto (Brito \& Silveira, 2005), com a transformação de um fluxo antecipado de investimento em fluxos correntes de pagamento por serviços prestados (Comissão das Comunidades Europeias, 2004). 
Como no caso da terceirização, a literatura também assinala problemas e limites no uso das PPPs, a começar pelos presumidos ganhos de eficiência que elas aportam. Ainda que vários estudos aplicados a países que adotaram o instrumento indiquem reduções de custos na prestação de serviços, comparativamente à provisão direta pelo setor público, ${ }^{7}$ há que se considerar o tipo de enfoque utilizado em tais análises. Em se tratando de prestação de serviço público, não se podem negligenciar, na avaliação do resultado, aspectos atinentes às externalidades positivas, cuja incorporação transcende abordagens informadas por critérios mais estritos de eficiência produtiva, típicos da lógica empresarial. Ao lado disso, existem expressivos custos de transação incorridos pelo setor público no processo, referentes à estruturação, contratação e monitoramento da parceria - atividades exigentes em termos de habilidades e conhecimentos especializados -, que devem ser levados em conta, embora não necessariamente o sejam. A questão dos ganhos de inovação revela-se mais controversa (Skelcher, 2007), sem evidências empíricas sólidas de sua ocorrência. No tocante à ampliação do espaço orçamentário, sua contraface é o comprometimento de receita futura, introduzindo um elemento de rigidez orçamentária, numa perspectiva de longo prazo, para o ente estatal responsável pelo financiamento ao esquema (Skelcher, 2007; Brito \& Silveira, 2005), limitando as escolhas de gastos abertas ao mesmo.

Junto com a intensificação da delegação da prestação de serviços públicos a entes não estatais, a agencificação emerge, no contexto do reformismo da NPM, como um instrumento de desconcentração intragovernamental em busca de níveis mais elevados de responsividade e desempenho de órgãos da administração pública. A agencificação expressa um processo de redesenho organizacional, focada na administração indireta, por meio da "individualização de entidades voltadas a propósitos específicos" (Pacheco, 2010: 196), designadas genericamente como agências. Reconfigurada como agência, a entidade governamental passa a dispor de mecanismos diferenciados de gestão, que lhe conferem maior autonomia decisória na alocação de recursos, comprometendo-se, em contrapartida, com a obtenção de determinados resultados, formalmente acordados por meio de contrato.

As principais críticas dirigidas à agencificação têm a ver com as consequências não pretendidas que acompanham sua implementação. Destaca-se, nesse contexto, a criação de um tecido organizacional mais fragmentado, com o aumento das unidades administrativas, criando inter-relações mais complexas e dinâmicas entre elas, o que traz não apenas maior dificuldade de coordenação na formulação e implementação de políticas públicas, como torna mais difícil, para o cidadão, entender os arranjos internos do Estado (Carneiro \& Menicucci, 2011). Outro aspecto refere-se ao efetivo controle da atuação das agências, tendo em vista as autonomias decisórias que lhes são concedidas. Não podem ser esquecidos, ademais, riscos de erosão da legitimidade e confiança, cujo fundamento primário são as regras da burocracia, flexibilizadas no processo de constituição de agências.

$\mathrm{Na}$ análise que faz da experiência internacional, focada em países da Organização para a Cooperação e Desenvolvimento Econômico (OCDE), Blöndal (2005) nota que a terceirização pode ser, e o é, aplicada de forma ampla. Por meio do instrumento, buscam-se ganhos de responsividade e

\footnotetext{
${ }^{7}$ Alguns desses estudos são mencionados por Skelcher (2007).
} 
eficiência na prestação de serviços, consoante as premissas da NPM. Manning e colaboradores (2009) observam, contudo, que, na América Latina, o que move a prestação alternativa de serviços tem a ver, em larga medida, com a disfuncionalidade de suas estruturas administrativas, em termos de capacidade técnica e operacional. O Brasil aproxima-se mais da realidade latino-americana que da OCDE, notadamente no que se refere aos níveis subnacionais de governo.

A terceirização não constitui fenômeno recente no país, como mostra sua previsão no âmbito do decreto-lei n. 200/1967. ${ }^{8}$ Na década de 1990, a lei n. 8.666/1993, que institui normas para licitações e contratos da administração pública, tratou também da matéria, permitindo que "as obras ou serviços sejam prestados por execução direta ou indireta" (Di Pietro, 1997: 118). De acordo com a regulamentação então instituída, a terceirização pode ser adotada em atividades instrumentais ao funcionamento da administração pública, sendo necessariamente precedida por licitação. Não se aplica, contudo, às atividades de cunho finalístico, à exceção dos serviços públicos que venham a ser objeto de concessão. À mesma época, a edição da lei n. 8.745 regulamentou a utilização do contrato temporário de pessoal, sem requisito de concurso público, para atender situações temporárias e de excepcional interesse público nelas descritas. A edição do decreto n. 2.271/1997 reafirmou, no âmbito do governo federal, o direcionamento da terceirização para as atividades acessórias, instrumentais ou complementares aos assuntos de natureza finalística, formalmente de competência dos órgãos e entidades da administração direta e indireta.

Mais recentemente, a LRF procurou restringir o uso indiscriminado da terceirização, estabelecendo que, nos contratos envolvendo trabalhadores terceirizados em substituição a servidores e empregados públicos, os valores envolvidos serão contabilizados como "outras despesas de pessoal". São restrições que não bloqueiam sua utilização na gestão de atividades exclusivas do Estado, como a administração de presídios (Tourinho, 2008), ou de atividades não exclusivas, como a saúde (Pereira, 2004; Pires, 2008) e a assistência social (Raichelis, 2010), envolvendo tanto empresas privadas de serviços e assessoria quanto cooperativas de trabalhadores. Embora não bloqueiem a terceirização, as dificuldades institucionais interpostas à sua utilização vêm estimulando a estruturação de novos arranjos organizacionais na gestão de atividades não exclusivas do Estado, sob a forma de OS e Oscip.

Nos termos do PDRAE, as OSs se configuram como "entidades de direito privado que, por iniciativa do Poder Executivo, obtêm autorização legislativa para celebrar contrato de gestão com esse poder, e assim ter direito a dotação orçamentária" (Brasil, 1995: 74). O modelo foi regulamentado por meio da lei n. 9.637/1998, que prevê a concessão de autonomias gerenciais às entidades assim qualificadas, atrelando-a à celebração de contratos de gestão. As flexibilidades administrativas previstas são relativamente amplas, cabendo destacar a possibilidade de contratar e demitir funcionários pelas regras da CLT e de adquirir bens e serviços com base em regimento próprio, e não nos dispositivos da lei n. 8.666/1993. De acordo com a legislação, a qualificação abrange as áreas de ensino, pesquisa e desenvolvimento tecnológico, proteção e preservação do meio ambiente e saúde.

\footnotetext{
${ }^{8}$ Como observa Di Pietro (1997: 118), o mencionado decreto "já previa a possibilidade de a Administração desobrigar-se da execução de tarefas executivas mediante a execução indireta, mediante contrato".
} 
Embora tenha sido o responsável por sua introdução, o governo federal pouco vem se utilizando da parceria com OSs. Transcorrida uma década de promulgação da regulamentação do modelo, havia apenas seis entidades qualificadas e com contratos de gestão vigentes no âmbito da administração federal $^{9}$ (Brasil, 2010), quase todas na área de pesquisa e desenvolvimento tecnológico. Trata-se de resultado que reflete, em parte, a polêmica em torno do modelo, questionado em sua legalidade por Ação Direta de Inconstitucionalidade (ADI), ${ }^{10}$ o que trouxe "insegurança para os atores que estavam envolvidos no processo de criação dessas instituições" (Torres, 2007: 73). Mais recentemente, o governo federal propôs a instituição do modelo de fundação pública de direito privado, mais conhecido como fundação estatal. A iniciativa foi objeto do projeto de lei complementar n. 92/2007 que, até o final de 2013, ainda se encontrava em tramitação no Congresso Nacional. O modelo aplica-se a áreas que confluem, em larga medida, para aquelas previstas na regulamentação das OSs. Alguns estados, como Bahia e Rio de Janeiro, já aprovaram legislação própria sobre a matéria e vêm ensaiando a aplicação do modelo na área da saúde.

É na esfera subnacional de governo que a OS vem encontrando terreno mais fértil. De acordo com estudo da Secretaria de Gestão (Seges) do Ministério do Planejamento, Orçamento e Gestão (Brasil, 2010), nada menos que 15 estados e 42 municípios haviam criado regulamentação própria da matéria até o ano de 2008, em sua maior parte tomando como referência a legislação federal. Nota-se, em diversas legislações estaduais e, principalmente, em legislações municipais, uma maior amplitude de áreas para a atuação das OSs, sinalizando uma maior predisposição em aplicar o modelo. Pelo mesmo estudo, existiam, em 2008, 112 OSs qualificadas por governos estaduais e outras 52 por governos municipais, embora nem todas tivessem, à época, contratos de gestão celebrados com a administração pública.

A área da saúde é uma das que mais se destacam no tocante à parceirização com OS na esfera subnacional de governo. A adoção do modelo, contudo, tem se processado sem o adequado aparelhamento da administração pública, enquanto contratante, para zelar pela qualidade do serviço prestado pela contratada. É o que mostra auditoria realizada pelo TCU, em 2012, nos estados de São Paulo, Bahia, Paraíba, Paraná e Rio de Janeiro, referente à transferência do gerenciamento de serviços públicos de saúde a OSs. Tal auditoria encontrou problemas em todos os contratos de gestão examinados, envolvendo tanto a fase de contratação quanto a de acompanhamento da execução das atividades pelas OSs. ${ }^{11}$ Segundo a análise realizada, as falhas e irregularidades encontradas refletem, em larga medida, déficits de capacidade gerencial das administrações envolvidas, o que se expressa em equipes reduzidas e sem a necessária qualificação.

\footnotetext{
9 A Associação Brasileira para o Uso Sustentável da Biodiversidade da Amazônia - Biomazônia, que havia sido qualificada como OS em 1999, teve seu contrato de gestão rompido em 2005, junto com a desqualificação da organização.

${ }^{10}$ ADI 1923 foi ajuizada pelo Partido dos Trabalhadores e pelo Partido Democrático Trabalhista, em 1998, contra a natureza jurídica das OSs.

${ }^{11}$ Os principais problemas ou irregularidades constatadas envolvem: o processo decisório relativo à terceirização não demonstra que esta constitui a melhor opção para o setor público; a qualificação e a seleção são, em muitos casos, mera formalidade; a delegação inclui, em alguns casos, atividades exclusivas do poder público; contratação sem fundamentação legal; ausência de indicadores para uma adequada avaliação do desempenho da OS; e controle insuficiente para garantir a regularidade na gestão dos recursos (TCU, 2014b).
} 
No entanto, a despeito dos problemas explicitados pela auditoria do TCU, é de se esperar a adesão de novos governos subnacionais ao modelo. ${ }^{12}$ À medida que a parceria com OSs se difunde, e ela vem se difundindo, outros governos podem considerar a opção de adotá-la, por isomorfismo mimético, ${ }^{13}$ avaliando-a como uma alternativa à construção de capacidade para implementar diretamente atividades de sua competência, sem o respaldo de uma análise mais criteriosa da conveniência e dos riscos de tal decisão.

Ao lado das OSs, outra forma de transferência da gestão da prestação de serviços públicos à população consiste na parceria com as Oscips. Instituído na esfera do governo federal pela lei n. 9.790/1999 e regulamentado pelo decreto n. 3.10/1999, o modelo envolve a qualificação, pelo Ministério da Justiça (MJ), de associação ou fundação civil sem fins lucrativos, criada por particulares, para atuar em áreas que se configuram como atividades não exclusivas do Estado. A qualificação como Oscip permite que a entidade se credencie para celebrar parcerias com órgãos governamentais, embora não exista nenhuma garantia de que isso venha a ocorrer. A justificativa para a proposição do referido modelo consiste na criação de uma alternativa "mais ágil e menos burocrática de transferência de recursos" (Torres, 2007: 80) a essas organizações, comparativamente ao convênio, tradicionalmente usado com tal finalidade.

No caso das Oscips, ainda que a legislação federal aplique-se aos governos subnacionais, alguns estados e municípios também vêm editando legislação própria sobre a matéria. De acordo com estudo da Seges (Brasil, 2010), dez estados e 16 municípios haviam promulgado, até 2008, lei ou norma específica sobre Oscip. No referido ano, existiam 5.050 entidades qualificadas pelo poder público nas três esferas de governo, em sua ampla maioria, 96,2\% do total, pelo governo federal. No entanto, apenas uma pequena fração conseguira celebrar parceria com o poder público. Das 4.856 entidades qualificadas pelo governo federal, 73 tinham contratos com o governo federal, e outras seis com estados e municípios, representando $1,6 \%$ do total. No que toca às entidades qualificadas por estados, 15 das 167 existentes, representando 9,0\% do total, tinham parcerias celebradas, quase todas com o governo mineiro. Já no caso dos municípios, nenhuma das 27 entidades por eles qualificadas tinha parceria celebrada. No balanço geral, tão somente 1,8\% das Oscips existentes à época contavam com parceria com a administração pública. Por sua vez, o número de parcerias celebradas alcançava 283 (Brasil, 2010), com uma média de 3,0 contratos por Oscip.

Como no caso das OSs, a adoção do modelo das Oscips tem se processado sem o adequado aparelhamento da administração pública para zelar pela qualidade do serviço prestado pela entidade contratada, como mostra relatório de auditoria realizado pela Controladoria-Geral da União (CGU) em 25 termos de parceria celebrados pelo MJ com Oscips, referentes ao período de 2008 a 2011. Tal auditoria encontrou impropriedades em 21 dos 25 termos auditados, envolvendo problemas variados, como execução parcial das metas e objetivos propostos, pagamentos indevidos, ausência

\footnotetext{
${ }^{12}$ Para fins de ilustração, o governo do estado do Rio de Janeiro promulgou legislação referente à matéria em 2009, e o de Rondônia o fez em 2011. O mesmo se passa na esfera dos municípios, dentre os quais o Rio de Janeiro.

${ }^{13}$ Isomorfismo mimético consiste na reprodução, por uma dada organização, de práticas adotadas por organizações similares, tomando-as como adequadas, sem uma preocupação mais efetiva com os resultados e as consequências da escolha feita.
} 
de comprovação de bens adquiridos e contratações de serviços com irregularidades, dentre outros. Tão ou mais importante, a CGU associou as irregularidades constatadas à fragilidade e estruturação inadequada dos órgãos responsáveis pela parceria, no âmbito do MJ, para o desempenho das atividades de supervisão e fiscalização das atuações das Oscips (Brasil, 2014b). Não se pode esperar situação distinta nos níveis subnacionais de governo, cujas burocracias são, reconhecidamente, menos profissionalizadas que a federal.

O quantitativo relativamente modesto de parcerias celebradas por Oscips revela que este arranjo organizacional ainda apresenta um alcance limitado como alternativa de desconcentração da gestão na prestação de serviços públicos. Tal resultado, contudo, parece não influenciar a disposição de novas entidades em obter a qualificação. De acordo com dados do MJ, o número de entidades qualificadas pelo governo federal somava, em 2012, um total de 6.565 Oscips, com um crescimento de 35,2\% em relação ao total existente em 2008.

Ainda que a evolução do número de entidades qualificadas como Oscip sinalize a institucionalização do modelo, as relações do setor público com entidades privadas sem fins lucrativos por meio de convênios ${ }^{14}$ não apenas mantêm-se muito expressivas como apresentam trajetória ascendente ao longo dos anos mais recentes. Segundo Lopez e Bueno (2012), os recursos transferidos pelo poder público às entidades sem fins lucrativos experimentaram uma variação real da ordem de 96,3\% entre 2002 e 2009. O crescimento é comum a todos os níveis de governo, e é mais expressivo no nível local, onde alcança $156,7 \%$ no período.

Repetem-se aqui, em escala ainda mais ampliada, as deficiências na capacidade técnica e operacional para gerenciar a relação contratual envolvida no repasse de recursos por meio de convênios e instrumentos congêneres, o que se evidencia em fiscalizações realizadas pelo TCU. É ilustrativo, a esse respeito, o relatório do acórdão 3.025/2010-Plenário, prolatado ao final de 2010, que trata de transferências voluntárias do governo federal a organizações não governamentais. Nele é destacado o desaparelhamento da administração pública federal, em termos de recursos materiais, humanos e tecnológicos, para o bom desempenho de suas atribuições, enquanto concedente, relativas a todas as fases do processo, que vão da proposição e formalização do convênio à análise da prestação de contas dos recursos repassados, passando pela fiscalização e acompanhamento das atividades, objetivos e metas acordadas. Em decorrência dessa fragilidade, de natureza sistêmica, materializa-se, na aplicação dos recursos pelas entidades convenentes, toda a sorte de ilícitos que as falhas no gerenciamento do convênio permitem. São constatações e conclusões que podem ser estendidas ao gerenciamento de convênios nos níveis subnacionais de governo (TCU, 2014a).

Como as terceirizações, as joint ventures não são fenômeno novo no país. A prestação de serviços públicos por entidades privadas remonta ao Império. Ao longo do tempo, o Estado brasileiro organizou as atividades setoriais sob diferentes modalidades, combinando a prestação direta do serviço, por empresa estatal, com a exploração por empresas privadas ou de economia mista, mediante concessão do poder público. Esse arranjo é reafirmado pela CF 1988 que, seguindo a esteira dos textos

\footnotetext{
${ }^{14}$ No caso do governo federal, o convênio aplica-se também a Oscips. No entanto, o repasse a esse tipo de entidade é relativamente pouco expressivo no conjunto de entidades sem fins lucrativos, representando $10 \%$ do total no período 2003-2011, conforme Lopes e Barone (2013).
} 
constitucionais anteriores, estabeleceu os princípios básicos do regime de concessão e permissão de serviços públicos, em que se destaca o imperativo da licitação. Para dar cumprimento ao ditame constitucional, que previa a elaboração de legislação dispondo sobre a concessão e permissão de serviço público, foram editadas as leis n. 8.987/1995 e n. 9.074/1995, ${ }^{15}$ cujas normas têm âmbito nacional, aplicando-se, portanto, a estados e municípios.

Seguindo a trajetória internacional, de retroação da intervenção direta do Estado na economia, a concessão da prestação de serviços públicos a empresas privadas volta a ganhar força no país a partir dos anos 1990. Nesse contexto, é lançado, no governo Collor, o Programa Nacional de Desestatização, por meio da lei n. 8.031/1990, que se inicia pela privatização de empresas nos setores de siderurgia, fertilizantes e petroquímica. A partir do primeiro governo Fernando Henrique Cardoso, o Programa Nacional de Desestatização entra em nova fase, na qual se confere maior prioridade à privatização como instrumento da política de ajuste fiscal com vistas à estabilização macroeconômica. A disposição renovada de levar em frente a redução das atividades empresariais do setor público se manifesta na criação, em 1995, do Conselho Nacional de Desestatização e no relançamento do Programa Nacional de Desestatização, com a edição da lei n. 9.491/1997, que revoga a lei n. 8.031/1990. A agenda privatizante inclui os setores de eletricidade, telecomunicações e transportes, ${ }^{16}$ alargando seu alcance para os governos estaduais. A partir do primeiro mandato de Lula, as concessões passam a ser movidas principalmente pela dificuldade na realização de investimentos em infraestrutura econômica advinda da persistência de uma política fiscal restritiva, comprometida com a obtenção de elevados superávits primários como suporte à estabilização monetária (Oliveira, 2012). Sem perspectivas de mudanças mais expressivas no campo fiscal, o cenário que se desenha é a intensificação das concessões, envolvendo o alargamento do escopo dos serviços prestados com base nas premissas do mercado.

Esse contexto de restrição fiscal impulsiona também a discussão sobre o uso das PPPs no país, que começa a ganhar fôlego em 2002 (Brito \& Silveira, 2005), e é regulamentado, de forma pioneira, pelo governo de Minas Gerais, em 2003. ${ }^{17}$ Outros estados, como São Paulo, Santa Catarina, Goiás e Ceará, seguem a iniciativa do governo mineiro e também se antecipam ao governo federal, promulgando legislações estaduais sobre a matéria em 2004. A regulamentação no âmbito federal ocorre ao final de 2004, o que se faz por meio da lei n. $11.079 .{ }^{18}$ O modelo brasileiro de PPP configura-se como uma espécie de alargamento da concessão, prevendo a possibilidade do ente estatal de se responsabilizar pela cobertura de parte da remuneração do parceiro privado, em complemento às receitas advindas da cobrança de tarifa ao usuário do serviço, ou de o ente estatal constituir o usuário direto ou indireto do serviço, responsabilizando-se integralmente pela remuneração do parceiro privado, dando forma, respectivamente, às denominadas concessões patrocinada e administrativa.

\footnotetext{
${ }^{15}$ Alteradas por diversas leis posteriormente editadas.

${ }^{16}$ As privatizações da prestação de serviços levaram à redefinição de seus marcos regulatórios, a exemplo da lei n. 9.427/1996, relativa aos serviços de energia elétrica, e da lei n. 9.472/1997, relativa aos serviços de telecomunicações.

${ }^{17}$ Lei n. 14.868, que dispõe sobre o Programa Estadual de Parcerias Público-Privadas.

${ }^{18}$ A partir de sua promulgação, alguns dispositivos das legislações estaduais que a antecederam, como a de Minas Gerais, tiveram que ser tacitamente revogadas por contrariarem a regulamentação nela expressa.
} 
Depois de regulamentada, a PPP "passou por um longo período sem aplicação efetiva" (Belsito \& Viana, 2013: 136), para ganhar impulso nos últimos anos da década passada, especialmente nas esferas subnacionais de governo. De acordo com informações do Ministério do Planejamento, Orçamento e Gestão (MPOG), 22 estados e o Distrito Federal já dispunham de legislação própria sobre a matéria, em 2010. O número de contratos assinados alcançava, então, um total de 17, distribuídos por seis estados e Distrito Federal. Progressivamente, o processo se estende aos governos locais, com destaque para as capitais e municípios das regiões Sul e Sudeste.

A despeito do quantitativo ainda relativamente modesto de contratos de PPPs celebrados no Brasil, a combinação da pressão pela realização de investimentos na expansão e melhoria da prestação de serviços públicos, pelo lado da demanda, com as limitações na capacidade de gasto do setor público, nas diferentes esferas de governo, pelo lado da oferta, tende a impulsionar a utilização do modelo. A adoção do Procedimento de Manifestação de Interesse (PMI), ${ }^{19}$ que reproduz, no país, instrumento usual no cenário internacional, por meio do qual a administração pública busca orientar a participação da iniciativa privada na estruturação e projetos de parceria de PPPs, aponta nessa direção. Balanço realizado pelo PPP Brasil (2012), mostra que, entre 2007 e 2012, foram publicados 73 PMIs no âmbito dos governos estaduais, dos quais 71\% do total referiam-se aos anos de 2011 e 2012. Esse incremento acelerado do lançamento de PMIs nos anos mais recentes, ainda que nem todos venham a se transformar em PPP, é um claro indicativo do crescente interesse governamental na parceirização com a iniciativa privada.

O espraiamento da percepção da PPP como alternativa para ampliar o espaço orçamentário na realização de investimentos em infraestrutura econômica e social, sustentado no isomorfismo institucional, deve levar um conjunto cada vez mais amplo de estados e municípios a explorar ao máximo, dentro dos limites institucionais atualmente estabelecidos, ${ }^{20}$ as possibilidades de uso do instrumento. Nesse esforço de atrair o interesse da iniciativa privada, os governos subnacionais vêm recorrendo a projetos de escopo muito variado. Como mostram as iniciativas setoriais já lançadas, os projetos mobilizados pelos governos subnacionais não se atêm às áreas mais convencionais para fins de concessão, especialmente transporte e saneamento básico, que comportam o uso da concessão patrocinada, avançando também em áreas como saúde e educação, para as quais a concessão administrativa se impõe. No âmbito do governo federal, a prioridade tem sido conferida ao uso da modalidade tradicional de concessão, em investimentos na área de infraestrutura econômica. No entanto, o progressivo esgotamento do estoque de investimentos setoriais com perspectivas mais favoráveis de retorno econômico, à medida que as concessões avançam, deve impulsionar as incursões na direção do uso das PPPs, atualmente ensaiadas em projetos nas áreas de irrigação e de defesa.

Por fim, a figura da agência autônoma, designada no PDRAE como agência executiva, foi regulamentada pela lei n. 9.649/1998, que trata da reorganização do Poder Executivo federal. A qualifi-

\footnotetext{
${ }^{19}$ Regulamentado no âmbito do governo federal pelo decreto n. 5.977/2006, o instrumento é destinado à apresentação de projetos, estudos ou investigações elaborados pela iniciativa privada, tendo em vista a modelagem de PPPs em projetos considerados prioritários pela administração pública, aplicando-se também à modelagem de concessões no formato convencional.

${ }^{20}$ Originalmente definido em $1 \%$ da Receita Corrente Líquida (RCL), o limite permitido de despesas em pagamento de contratos de PPP foi elevado, no caso de estados e municípios, para 3\% da RCL pela lei n. 12.024/2009 e, pouco depois, para 5\% da RCL, por força da lei n. 12.766/2012.
} 
cação como agência executiva, contudo, suscitou reduzido interesse nas autarquias e fundações da administração federal. Esse novo formato organizacional encontrou maior ressonância sob a forma de agência reguladora, o que reflete o processo de desestatização formalmente desencadeado nos anos 1990. Inspiradas no modelo de regulação americano, as agências reguladoras, em trajetória distinta das agências executivas, vêm adquirindo crescente institucionalidade na administração pública brasileira. O movimento se inicia com a criação da Agência Nacional de Energia Elétrica (Aneel), em 1996, à qual se seguem a Agência Nacional de Telecomunicações (Anatel) e a Agência Nacional do Petróleo, Gás Natural e Biocombustíveis (ANP), ambas datadas de 1997, ${ }^{21}$ e se estende também ao nível subnacional de governo. ${ }^{22}$

Do exame empreendido emergem dois movimentos principais de reconfiguração dos arranjos organizacionais da administração pública brasileira, cuja dinâmica mais recente sinaliza para uma trajetória de progressiva consolidação. O primeiro envolve parcerias com entidades sem fins lucrativos e congêneres, e o segundo, parcerias com empresas privadas. Em ambos os casos, são movimentos que não deslocam ou substituem formas convencionais de relação do setor público com tais entidades e empresas - respectivamente, o convênio e a concessão - mas as complementam, implicando uma maior diferenciação do tecido organizacional responsável pela prestação de serviços públicos à sociedade. A delegação da gestão a entidades sem fins lucrativos, o que inclui arranjos como as OSs e as Oscips, aplica-se à prestação de serviços na área social e tem sido utilizada pelos governos subnacionais como uma alternativa à execução direta da atividade, que, embora não necessariamente mais eficiente, reduz a pressão pela expansão dos respectivos aparatos técnicos e administrativos.

Por sua vez, a delegação da gestão a empresas privadas, lastreada no instrumento da concessão, cujo escopo vem sendo alargado com a adoção das PPPs, aplica-se à prestação de serviços nas áreas de infraestrutura econômica e social, e tem sido crescentemente utilizada pelos governos, tanto federal quanto estadual e local, como uma alternativa de financiamento, em face das limitações no tocante à capacidade de realizar investimentos com recursos próprios. Não custa lembrar, no entanto, que a decisão de delegar meramente altera a natureza das atividades desempenhadas pelo governo, não o eximindo de suas responsabilidades. Delegar envolve contratar, demandando capacidade de negociar e monitorar o contrato que, como visto, revela insuficiente aparelhamento na administração pública brasileira, notadamente na esfera subnacional de governo.

\section{Descentralização político-administrativa e o papel dos municípios}

Descentralização constitui um termo empregado em sentidos variados, que vão desde a transferência da prestação de serviços para empresas privadas ou organizações governamentais até a redistribuição ampla de poder entre níveis distintos de governo, passando pela delegação de funções e responsabilidades entre órgãos ou unidades de uma mesma esfera de governo (Pollitt, 2007). Para os

\footnotetext{
${ }^{21}$ As mencionadas agências foram instituídas, respectivamente, pelas leis n. 9.427/1996, n. 9.472/1997 e n. 9.478/1997. Posteriormente, outras sete agências foram instituídas e uma oitava - a Agência Nacional de Mineração (ANM) encontra-se em processo de criação.

${ }^{22}$ A título de ilustração, a Associação Brasileira de Agências de Regulação (Abar) conta, em seu quadro de entidades associadas, com 27 agências reguladoras estaduais e outras cinco municipais.
} 
propósitos aqui pretendidos, restringe-se à aplicação do termo ao campo das relações intergovernamentais, o que remete à redistribuição de poder decisório do nível central para os níveis subnacionais de governo, com destaque para o local.

O exame da questão implica considerações acerca de duas questões principais, que conferem materialidade ao padrão das relações estabelecidas entre os diferentes níveis de governo. O primeiro relaciona-se com a forma como se dá a redistribuição de responsabilidades, o que é particularmente relevante quando estão envolvidas funções ou competências partilhadas. O compartilhamento de funções demanda o desenho de arranjos institucionais com vistas a articular a atuação dos diferentes níveis de governo, sem o qual há um risco não desprezível de fragmentação excessiva e dispersão de esforços na implementação de uma dada política. O segundo refere-se à redistribuição financeira, envolvendo mecanismos de transferência de recursos do nível central para os governos subnacionais, de forma a assegurar padrões mínimos de qualidade nos serviços prestados à população.

Ainda que os argumentos acerca da descentralização sejam, conforme Pollitt (2007: 372), "tão antigos como o estudo da administração pública", o tema persiste complexo e controverso (Przeworski, 1999), sinalizando a existência de posições favoráveis e contrárias à mesma. Os aspectos positivos comumente associados à descentralização remetem, em geral, ao aumento da eficiência e efetividade na alocação dos recursos públicos com vistas à provisão de bens e serviços à população, na dimensão administrativa, e à maior democratização no exercício da atividade governativa, na dimensão política. Por sua vez, os aspectos negativos apontam na direção oposta, ou seja, riscos de ineficiência alocativa, na dimensão administrativa, e de fragilização do controle da sociedade sobre o governo, na dimensão política.

A descentralização potencializa ganhos de eficiência e de efetividade ao favorecer um melhor ajustamento da oferta dos bens ou serviços públicos às preferências e necessidades da população neles interessada, além de facilitar a experimentação e a introdução de inovações (Pollitt, 2007; Beramendi, 2009). Quanto ao primeiro aspecto, o ponto relevante é a possibilidade da adoção de soluções não padronizadas na provisão do bem público, incorporando uma avaliação mais criteriosa e realista, baseada nas preferências dos usuários, dos custos e benefícios sociais de diferentes alternativas para lidar com a questão. No tocante ao segundo aspecto, os governos locais seriam compelidos, pela maior pressão da demanda da população, a usar a autonomia decisória de que dispõem para buscar soluções criativas e inovadoras capazes de refletir as peculiaridades de suas respectivas jurisdições (Abrucio, 2006).

O pressuposto básico que orienta a percepção de que a descentralização influencia positivamente a democracia é o de que a maior aproximação entre governantes e governados favorece o controle social da população sobre o governo, aumentando não só a responsividade como também a transparência das ações do poder público. $\mathrm{O}$ fato de a gestão da coisa pública ficar mais próxima da população facilita o encaminhamento das demandas ou reivindicações de interesses constituídos da sociedade ao governo, ao mesmo tempo que aumenta a probabilidade de difusão de informações de interesse coletivo e de instituição de canais mais efetivos de fiscalização da atividade governativa. Outra linha de interpretação enfatiza a descentralização como instrumento para o desenvolvimento 
de uma cultura cívica direcionada à busca de soluções para os problemas coletivos ancoradas em organizações da sociedade civil e, portanto, menos dependentes do Estado.

No entanto, descentralizar possui, reconhecidamente, limites administrativos e políticos, podendo apresentar efeitos perversos caso alguns requisitos não se façam presentes na estruturação organizacional da instância local de governo e nos arranjos sociais e institucionais prevalecentes em sua respectiva jurisdição. A literatura destaca dois tipos principais de problemas que podem influenciar e, no extremo, comprometer os resultados esperados da descentralização, dando suporte a argumentos a favor da centralização. O primeiro refere-se a riscos de ineficiência econômica e social na alocação de recursos, envolvendo questões atinentes tanto à formulação quanto à implementação de políticas públicas. O segundo guarda relação com a capacidade de organização e mobilização política das comunidades locais, que se reflete na qualidade do controle social sobre o governo.

Os possíveis ganhos de eficiência advindos da descentralização supõem a existência de capacidade técnica e de mobilização de recursos das administrações locais compatíveis com o desempenho das funções que lhes competem. A extensão ou abrangência da descentralização deve considerar as distintas exigências de capacidade gerencial e financeira das diferentes atribuições do poder público e as capacidades efetivamente existentes nos níveis locais de governo, de forma a evitar padrões muito desiguais na quantidade e, principalmente, na qualidade da provisão de bens e serviços à população.

Como observa Pollitt (2007), os governos locais se defrontam com maior dificuldade no tocante a recrutar e reter uma massa crítica de profissionais especializados, comparativamente ao nível central de governo. Um dos principais riscos é a ausência de padrões mínimos na provisão de serviços sociais básicos à população, penalizando, regra geral, as comunidades mais pobres, as quais não podem prescindir da atuação do poder público. Sobre a questão, Pollitt (2007: 381) pondera que a "centralização, sob a forma de padronização, leva a maior equidade". Seguindo com o autor, "todos os cidadãos, em circunstância similar, recebem o mesmo serviço". Ao lado disso, a descentralização pode criar dificuldades na coordenação e no controle da implementação de políticas públicas partilhadas por diferentes níveis de governo.

A principal contribuição da descentralização à democracia, destacada pela literatura, que se traduz na facilitação à participação política, instrumentalizando "formas mais efetivas de controle sobre a agenda e sobre as ações de governo" (Arretche: 1996: 6), por sua vez, não é linear nem automática. Ao contrário, descentralizar pode ter efeitos adversos, favorecendo a adoção de padrões arcaicos de condução da atividade governativa no nível local, lesivos aos interesses da coletividade. Entre tais efeitos, podem ser relacionados a maior porosidade da administração pública à inserção de interesses particularistas, com o risco não desprezível de captura do poder político por determinados grupos que se alternam, ou não, no comando do governo, bem como a maior propensão à cooptação e obtenção de apoio político por meio de práticas de natureza clientelista.

Depreende-se, das considerações anteriores que, para prevalecerem os efeitos positivos atribuídos à descentralização, faz-se necessário o preenchimento de determinados requisitos mínimos, quer na dimensão administrativa quer na dimensão política das instâncias locais de governo. Na esfera administrativa, o ponto saliente consiste na criação de uma burocracia profissionalizada, capaz de 
assegurar maior agilidade e eficiência à gestão pública e de dar respostas de melhor qualidade às demandas da população. Na esfera política, é indispensável a construção de "instituições cuja natureza e cujas formas de atuação sejam compatíveis com os princípios democráticos que norteiam os resultados que se espera produzir" (Arretche, 1996: 6), ou seja, que não se prendam apenas à intenção ritualística de mero formalismo burocrático.

A descentralização brasileira do período contemporâneo não é pautada primariamente por razões relacionadas à busca de maior eficiência alocativa na prestação de serviços à população, ainda que considerações desta natureza sejam tacitamente observadas ao longo de sua implementação. Trata-se, como já mencionado, de um empreendimento de fundamentação política, articulado à redemocratização, cujo marco é a promulgação da CF 1988. O novo texto constitucional promove um redesenho no arranjo federativo do país, no qual o município é incorporado, juntamente com os estados, como parte integrante da federação (Souza, 2005). Essa descentralização se traduz na ampliação da autonomia fiscal, política e administrativa dos municípios, ao lado do alargamento de seus papéis e competências, em que se destaca a definição de funções partilhadas na área das políticas sociais.

Os impactos mais imediatos da descentralização preconizada pela CF 1988 se deram no campo fiscal, já que se ancoravam em dispositivos autoaplicáveis, que prescindiam de regulamentação por legislação infraconstitucional para a entrada em vigor. De fato, o novo texto constitucional patrocinou significativo alargamento da base de financiamento dos municípios, tanto pela ampliação de seu poder de taxação quanto, e principalmente, pela elevação do volume de repasse de transferências compulsórias de recursos por parte dos governos estadual e federal (Affonso \& Silva, 1996; Arretche, 2000; Oliveira, 2003). Esse incremento de receita, no entanto, não se fez acompanhar da concomitante assunção de funções ampliadas na gestão de políticas sociais pelos governos locais, também objeto de intenções descentralizantes. A despeito de os municípios passarem a dispor de uma maior capacidade de financiamento e, por consequência, de assumirem novas e ampliadas funções, a descentralização no campo social será gradativa, exigindo um esforço de engenharia institucional comandado pelo governo federal.

O processo é deflagrado nos anos 1990 e se aprofunda na década seguinte, quando as relações intergovernamentais se intensificam e adquirem maior complexidade. Tal processo não envolve apenas a transferência de responsabilidades ou atribuições, mas a construção mesma da política pública, uma vez que o sistema de proteção social brasileiro prevalecente até a promulgação da CF 1988, descrito por Arretche (2000: 46) como um "conjunto disperso, fragmentado, com reduzidos índices de cobertura e fragilmente financiado de iniciativas governamentais na área social", teve sua concepção profundamente alterada pelo novo texto constitucional. A área da saúde ilustra bem a questão, com a criação do Sistema Único de Saúde (SUS) por determinação constitucional. E é exatamente na área da saúde que começa a tomar forma o protagonismo do governo federal como normatizador e coordenador das políticas sociais no país.

O passo inicial para a regulamentação do SUS é dado pela lei n. 8.080/1990, que estabelece as atribuições dos diferentes níveis de governo no tocante a competências e gestão. Em complemento à lei n. 8.080, edita-se a lei n. 8.142/1990, que define as formas de transferência de recursos entre as esferas de governo, com a constituição do Fundo Nacional de Saúde e a especificação das condições 
para acesso ao mesmo por parte dos estados e dos municípios, ${ }^{23}$ bem como as formas de participação social na política setorial. No decorrer da década de 1990 e seguintes, o país continua construindo um sistema nacional de saúde, de natureza pública, universal e gratuito, delineado nas leis mencionadas. Esse processo se faz por meio de normas - as Normas Operacionais Básicas (NOBs) e as Normas Operacionais de Assistência à Saúde (Noas) - e de portarias editadas pelo governo federal, o qual se encarrega da formulação da política setorial e da coordenação das ações intergovernamentais no âmbito da mesma.

A regulamentação básica para a descentralização da gestão irá se fundamentar em dois mecanismos principais: a habilitação para assunção de funções e o incentivo ou indução à adesão ao sistema. A habilitação foi introduzida pela NOB-SUS/1991, por meio da qual se verifica a capacidade operacional dos estados e municípios de assumir a implementação de ações da política de saúde em suas respectivas jurisdições. Reconhece-se que a descentralização, como destaca a literatura, não pode prescindir da existência de condições técnicas e operacionais - em termos de estrutura física, organizacional e de recursos humanos - minimamente compatíveis com o desempenho da função ou atividade que se quer descentralizar.

A NOB-SUS/1993 encarregou-se de definir distintas modalidades de habilitação ao SUS, ${ }^{24}$ "as quais supõem graus distintos de responsabilidade sobre a gestão dos serviços" (Arretche, 2000: 206-207), portadores de graus distintos de complexidade. A indução ancora-se em incentivos financeiros, sob a forma de transferências universais condicionadas, em que o acesso a recursos disponibilizados pela política federal requer a prévia adesão aos objetivos nela traçados. A esse mecanismo de indução se soma a emenda constitucional n. 29/2000, que determinou gastos mínimos compulsórios em ações de saúde para estados e municípios. ${ }^{25}$ Refletindo os efeitos dos mecanismos de indução, a totalidade dos governos subnacionais - estados e municípios - optou por se integrar ao sistema nacional, no âmbito do qual desempenham ações da política setorial definida pelo governo federal, o que se aplica especialmente aos governos locais. Como salienta Arretche (2012: 163), o uso combinado da autoridade normativa e do poder de gasto permite ao governo federal direcionar a atuação dos governos municipais para "programas de atenção básica à saúde, contratação de médicos, enfermeiros e atendentes de saúde, bem como acesso gratuito a principais medicamentos, cobertura vacinal e atendimento pré-natal", esvaziando, na prática, a autonomia decisória que formalmente os reveste.

A área da assistência social segue, em linhas gerais, a concepção de política pública delineada para a saúde, convergindo para a construção do Sistema Único de Assistência Social (Suas), que se articula em torno da execução descentralizada das atividades e ações da política setorial, cuja formulação geral fica a cargo do governo federal. O marco inicial do processo de regulamentação da gestão da política de assistência social consiste na aprovação da Lei Orgânica da Assistência Social (Loas),

\footnotetext{
${ }^{23}$ Para o acesso aos recursos disponibilizados pelo governo federal, os municípios devem dispor de fundo municipal de saúde, órgão gestor, conselho de saúde e plano de saúde, entre outros requisitos.

${ }^{24}$ Posteriormente alterada pela NOB-SUS 01/96 e pelas Noas-SUS/2001 e 2002.

${ }^{25}$ No caso dos estados, a fração da receita destinada a gastos em saúde começa com o patamar de $7 \%$ em 2000 para alcançar $12 \%$ a partir de 2004; no caso dos municípios, a fração sobe dos mesmos $7 \%$ da receita em 2000 para $15 \%$ a partir de 2004.
} 
em 1993, que define o município como instância privilegiada da execução de ações e serviços assistenciais, seja de forma direta seja por meio da celebração de convênios com entidades assistenciais. Nos termos da Loas, cabe ao governo federal o "papel de financiador e normatizador, e aos municípios o papel de formulador e executor das políticas no plano local", com atribuições residuais reservadas aos estados (Arretche, 2000: 175). Para o exercício de seu papel de financiador, o governo federal instituiu, de forma similar à política de saúde, o Fundo Nacional de Assistência Social, ${ }^{26}$ cujo acesso requer o preenchimento de um conjunto de requisitos técnicos e operacionais, que contempla, no caso dos municípios, a criação de fundo, conselho, plano e órgão gestor de assistência social.

Num processo lento de regulamentação, o aprimoramento e o adensamento da política setorial somente vão se dar na década seguinte, com a edição da NOB-Suas/2005, ${ }^{27}$ que dispôs sobre os níveis de gestão, além de definir critérios mais objetivos e transparentes de financiamento e repasse de recursos. No entanto, a efetiva estruturação do Suas ocorre, a rigor, com a promulgação da lei n. 12.435/2011, que garante o ordenamento jurídico para as diretrizes de descentralização e participação da sociedade civil na concepção, gestão e controle da política setorial. A mencionada legislação define responsabilidades e competências; reafirma o cofinanciamento por meio de transferências automáticas entre os fundos setoriais e da alocação de recursos próprios dos entes federados nestes fundos; e organiza as ações pelo grau de complexidade e natureza do atendimento em serviços de proteção social básica e especial. ${ }^{28}$ De acordo com dados do Ministério do Desenvolvimento Social e Combate à Fome (MDS), a quase totalidade dos municípios havia aderido ao Suas em 2012.

No caso da política habitacional, a CF 1988 estabelece também a competência comum dos diversos entes federados para promover programas na área, ainda que sem maiores indicações de responsabilidades e competências. E, diferentemente das políticas de saúde e assistência social, cujos marcos legais foram aprovados ainda nos anos 1990, a regulamentação da política setorial irá se processar mais tardiamente, já nos anos 2000. Sua estruturação se concretiza com a promulgação da lei n. 11.124/2005, que cria o Sistema Nacional de Habitação de Interesse Social (SNHIS) e o Fundo Nacional de Habitação de Interesse Social (FNHIS), além de instituir o conselho gestor do FNHIS. ${ }^{29} \mathrm{O}$ arcabouço normativo segue o molde da legislação das políticas sociais. Assim, para acessar os recursos do FNHIS, governos subnacionais devem criar conselhos e órgãos específicos, ao lado de instrumentos como cadastros, planos e fundos setoriais. No que diz respeito aos municípios, pesquisa coordenada por Arretche (2013) mostra, ao mesmo tempo, a força da legislação em induzir a adesão dos governos locais ao sistema e a dificuldade com as quais estes se defrontam em cumprir os requisitos administrativos e operacionais nela especificados.

\footnotetext{
${ }^{26}$ O Fundo Nacional de Assistência Social foi regulamentado pelo decreto n. 1.605/1995.

${ }^{27}$ Trata-se da primeira NOB que versa sobre o Suas, instituído na Política Nacional de Assistência Social, de 2004.

${ }^{28} \mathrm{~A}$ proteção social básica está voltada para a prevenção de situações de vulnerabilidade e risco social, tendo, como unidade referencial para a prestação do serviço, o Centro de Referência de Assistência Social (Cras). A proteção social especial orienta-se para a reconstrução de vínculos familiares e comunitários, bem como para a defesa de direitos, tendo, como unidade referencial para a prestação do serviço, o Centro de Referência Especializado de Assistência Social (Creas).

${ }^{29} \mathrm{~A}$ referida lei considera dois subsistemas - o de habitação de interesse social - correspondente às faixas de renda familiar de 0 a 3 e 3 a 5 salários mínimos - e o de habitação de mercado.
} 
Em 2012, a disposição de integrar o sistema alcançava 96,9\% dos municípios, enquanto a parcela daqueles que dispunham de fundo, conselho e plano setorial era de, respectivamente, 71,7\%, 68,2\% e $11,4 \%$ do total.

Outros avanços importantes promovidos pelo governo federal referem-se às áreas de saneamento ambiental, transporte e mobilidade urbana. A responsabilidade pelo delineamento das políticas setoriais ficou a cargo do Ministério das Cidades, criado em 2003. Em meados de 2004, a política urbana nas áreas mencionadas encontra-se consolidada em suas premissas gerais, objetivos e programas, e, nos anos seguintes, estabelecem-se os respectivos marcos regulatórios. O processo se inicia pela Política Nacional de Saneamento Básico, instituída pela lei n. 11.445/2007 e regulamentada pelo decreto n. 7.217/2010. De acordo com a regulamentação, a elaboração de planos setoriais pelos governos subnacionais passa a ser condição obrigatória para acesso a recursos federais a partir de 2014, sendo prescrito também o controle social por meio de órgão colegiado.

A Política Nacional de Resíduos Sólidos é objeto da lei n. 12.305/2010, cuja regulamentação se faz pelo decreto n. 7.404/2010. Como no caso da política de saneamento básico, a regulamentação prevê a elaboração de planos de resíduos sólidos urbanos como condição de acesso a recursos federais para a área, a partir de 2012, conferindo prioridade, na acessibilidade, a municípios que fizerem a opção por solução consorciada. Mais recentemente, o governo federal institui a Política Nacional de Mobilidade Urbana por meio da lei n. 12.587/2012. Nela, fica estabelecida a obrigatoriedade da elaboração de planos municipais de mobilidade urbana para municípios de população acima de 20 mil habitantes, num prazo de até três anos após sua edição, condicionando, como nas demais políticas setoriais, o acesso a recursos federais à sua existência.

A área da educação apresenta trajetória distinta das demais políticas sociais no tocante à descentralização, a começar pelo fato de a oferta de ensino fundamental já ser de responsabilidade de estados e municípios anteriormente à CF 1988. O novo texto constitucional reafirmou o ensino fundamental como função de competência comum desses entes federados, "estabelecendo apenas que os governos municipais deveriam dar prioridade" ao mesmo (Arretche, 2012: 166). Ao lado disso, estabeleceu vinculação de receita disponível de estados e municípios a gastos nas atividades de ensino, destinando $25 \%$ do total com tal finalidade. Além da função precípua de manutenção da rede federal de ensino superior e apoio à pós-graduação, coube ao governo federal, no caso da educação básica, apenas um papel supletivo no financiamento setorial, atuando como financiador de programas de merenda escolar e de "construção e capacitação das unidades escolares" (Arretche, 2012: 167), dentre outras ações.

Esse arranjo institucional, contudo, revelou-se insuficiente para fomentar a universalização e o adequado funcionamento do ensino fundamental obrigatório, consoante as diretrizes da Lei de Diretrizes e Bases da Educação Nacional - lei n. 9.439/1996 -, desembocando na criação do Fundo de Manutenção do Ensino e Valorização do Magistério (Fundef).$^{30} \mathrm{O}$ Fundef sinaliza a disposição do governo federal em assumir o papel de normatizador e coordenador da política setorial, deixando

\footnotetext{
${ }^{30} \mathrm{~A}$ instituição do Fundef se ancora na promulgação da emenda constitucional n. 14/1996, na lei n. 9.424/1996 e no decreto n. 2.264/1997 (Oliveira, 2003).
} 
a cargo dos governos subnacionais sua execução, ${ }^{31}$ na linha do modelo aplicado às demais áreas da política social. Na década seguinte, o Fundef, que vigorou de 1998 a 2006, foi substituído pelo Fundo de Manutenção e Desenvolvimento da Educação Básica e de Valorização dos Profissionais da Educação (Fundeb). ${ }^{32}$ Conforme Arretche (2012), o Fundeb adota regras similares às do Fundef. ${ }^{33}$ Suas principais inovações são a ampliação da cobertura para o ensino básico e a elevação de gasto do governo federal, que passa a assumir maiores responsabilidades no financiamento da política setorial.

Assim, induzida e comandada pelo governo federal, a descentralização revela-se um dos processos mais marcantes da gestão pública brasileira do período contemporâneo, que vem redesenhando a forma como os serviços públicos são prestados à população. Tal processo fica evidenciado nas profundas transformações transcorridas na estrutura do emprego público, na direção à sua municipalização. De uma participação quase residual em 1950 - 15,0\% do total -, o emprego público municipal experimenta aumentos sistemáticos de sua representatividade a partir dos anos 1970 e, especialmente, desde a promulgação da CF 1988, para se tornar majoritário na segunda metade da década de 1990, alcançando 42,0\% do total em 1999. Atualmente, os municípios são responsáveis por mais de 50,0\% do emprego público no país (Pessoa, 2003; Marconi, 2010).

Esse crescimento acelerado da representatividade do emprego público municipal denota que os governos locais estão buscando se aparelhar administrativamente para cumprir os novos papéis e responsabilidades que lhes foram atribuídos no texto constitucional. De fato, o incremento de mais de dois milhões de empregados no setor público ocorrido entre 1993 e 2007 se deve basicamente à expansão do emprego no nível local. Enquanto o emprego nos governos federal e estadual pouco variou no período - respectivamente, 5,5\% e 4,1\% -, o emprego municipal experimentou uma variação da ordem de $81,3 \%$ do total (Marconi, 2010). Dados mais atualizados do Instituto Brasileiro de Geografia e Estatística (IBGE) indicam que o emprego municipal continuou se expandindo, para alcançar 6.280.213 pessoas em 2012 - um incremento de 20,6\% em relação a 2007 (IBGE, 2012).

As informações referentes ao emprego público no nível municipal, ao mesmo tempo que atestam o êxito do governo federal em promover a adesão dos governos locais à descentralização no campo das políticas sociais, lançam luz sobre os desafios com os quais estes se defrontam quanto à construção de estruturas administrativas profissionalizadas para lidar com as crescentes responsabilidades e atribuições na prestação de serviços à população. Essa questão ganha particular relevância no contexto de limitada flexibilidade fiscal que marca a administração pública brasileira, em especial os níveis subnacionais de governo. Interessa destacar aqui, especificamente, o fato de o incremento da demanda por gastos dos municípios na área social, advindo da dinâmica descentralizante, não se fazer acompanhar de concomitante aumento em sua capacidade de financiamento. Embora seja

\footnotetext{
${ }^{31}$ O Fundef envolve uma espécie de minirreforma (Oliveira, 2003; Arretche, 2012), destinando, automaticamente, $15 \%$ das receitas de estados e municípios para um fundo estadual, redistribuídas, no interior de cada estado, entre governos estadual e municipais, de acordo com o respectivo número de matrículas no ensino fundamental oferecidas anualmente.

${ }^{32} \mathrm{O}$ Fundeb foi criado pela emenda constitucional n. 53/2006 e regulamentado pela lei n. 11.494/2007 e pelo decreto n. $6.253 / 2007$.

${ }^{33}$ Cabe destacar o aumento, de $15 \%$ para $20 \%$, da parcela das receitas vinculadas que são destinadas ao fundo.
} 
nítido o ganho de receita dos municípios no período determinado pelas mudanças introduzidas pela CF 1988, o processo perde fôlego nos anos mais recentes, com a participação dos governos locais estabilizando-se em torno do patamar de $20 \%$ da receita líquida total do setor público (Khair, 2013).

A despeito das dificuldades de natureza administrativa e financeira que marcam sua trajetória, a descentralização na área social parece um caminho sem volta na realidade brasileira. Os notáveis avanços na normatização das políticas setoriais, ainda que suscetíveis a novos aprimoramentos, como historicamente vêm ocorrendo, tendem a lhe conferir um grau de institucionalização de difícil reversão. Se isso é verdade, também o é a necessidade de se avançar além da indução da adesão dos municípios às políticas desenhadas pelo governo federal. A adesão não se transmuta automaticamente em adequada capacidade de gestão nem sinaliza sua efetiva existência. Assim, para que a descentralização possa proporcionar ganhos de eficiência na prestação de serviços à população e incrementos da democratização no exercício do poder público - virtudes que lhe são convencionalmente atribuídas -, há que se enfrentar o déficit de capacidade técnica e gerencial presente na esfera dos governos locais. Tal enfrentamento não se viabiliza sem o protagonismo e o apoio do governo federal. É nessa direção que aponta o lançamento recente do Programa Mais Médicos, ${ }^{34}$ com o objetivo de fortalecer a prestação de serviços de atenção básica à saúde no país, por meio de redução da carência de médicos em regiões consideradas prioritárias para o SUS.

\section{Governança democrática e as instâncias de participação}

O termo governança não é propriamente novo; é utilizado há muito tempo, com fins descritivos, significando "a ação ou forma de governar, isto é, de dirigir, guiar ou regular as condutas ou ações de indivíduos, organizações, nações ou associações multinacionais - públicas, privadas ou ambas" (Lynn Jr., 2012: 49). Sua reintrodução recente se dá com base na literatura anglo-saxônica, em que se destaca o trabalho de Willianson (1979), que tem um forte impacto nas abordagens relativas à relação entre lei e economia e, especificamente, à governança corporativa.

Não há uma abordagem unificada da temática da governança, o que reflete, em particular, as diversas áreas disciplinares e vertentes teóricas que se utilizam do termo. Não se tem, portanto, uma noção única, mas um conjunto não homogêneo de concepções, bem como de aplicações em diferentes domínios ou campos de conhecimento. A adjetivação do conceito - governança local, corporativa, democrática, participativa, regulatória, urbana - ilustra bem a questão, como evidencia a análise de Peters (2012).

Descartando-se efetuar uma revisão do emprego do termo - de suas variações conceituais e de seu potencial analítico, já realizada por diversos autores, como Levi-Faur (2012) -, importa destacar duas perspectivas. A primeira, de cunho normativo ou prescritivo, remete à ideia de "bom governo" e a seus atributos; a segunda, mais afeta ao enfoque aqui pretendido, ilumina analiticamente a dimensão relacional. Nesse sentido, em convergência com diversos autores, Stoker (1998) afirma que a noção de governança teria em vista capturar mudanças ocorridas nos governos e em sua relação com a sociedade, em ressonância com os debates políticos nas democracias ocidentais.

\footnotetext{
${ }^{34}$ O programa foi instituído pela medida provisória n. 621 , de agosto de 2013, convertida na lei n. 12.871, de outubro de 2013.
} 
Na análise de Klinj (2012), relevante para os objetivos deste trabalho, a governança não se refere ao governo tradicional nem ao "bom governo", tampouco às reformas no bojo da NPM. Remete, sim, às mudanças nas relações entre governo e atores visando à coordenação horizontal e a qualidade do processo decisório. $\mathrm{O}$ autor destaca o entrelaçamento da governança com a democracia, na medida em que a primeira tem em vista a inclusão e o envolvimento dos diferentes atores sociais nos processos de formulação e implementação das políticas públicas por meio de novos arranjos e modos de decisão compartilhados. Encampando possibilidades de participação nos processos decisórios, a perspectiva de governança favoreceria a legitimidade democrática, a accountability e a oportunidade de vocalização societária e de sua contribuição para as deliberações.

As linhas mais reflexivas e críticas que abordam a governança contemporânea, como já assinalado por Carneiro e Menicucci (2011), encaminham-se para a dimensão participativa-deliberativa. Desse modo, pode-se identificar um conjunto de trabalhos que ressituam a noção de governança com base na incorporação de elementos das teorias democráticas contemporâneas, em suas correntes de democracia deliberativa e participativa (Fung \& Wright, 2001; Fung, 2003; Klinj, 2012; Lynn Jr., 2012; Fisher, 2012). O núcleo comum desses empreendimentos está na ênfase conferida à participação da sociedade nos processos decisórios como um elemento central na noção de governança.

Também pode ser observado na literatura brasileira o emprego do termo governança democrática ou participativa, mais especificamente em referência à esfera local. Os trabalhos que empregam esse termo voltam-se, em grande parte, para a análise de instituições participativas, sobretudo dos conselhos municipais (Gohn, 2004; Cortes, 2005; Wampler, 2011). A noção de governança tem sido empregada como um recurso analítico, e às vezes retórico, para a abordagem da participação nesses espaços, com o foco privilegiado nos arranjos institucionais estabelecidos e suas consequências.

O ambiente que circunscreve a expansão inicial das experiências de participação institucionalizada no âmbito brasileiro pós1988 marca-se pela emergência de novos atores coletivos societários, pela reestruturação dos seus modelos de intervenção estatal, pelo processo de descentralização e ampliação da autonomia local, pelo alargamento dos direitos sociais e pelas premissas de democratização das relações entre Estado e sociedade. Nesse contexto, a governança democrática ou participativa pode ser associada às formas ampliadas de participação por meio das instituições participativas que foram cunhadas, possibilitando a inclusão política de atores societários nos processos decisórios institucionais. Sem a pretensão de análise das principais instituições participativas, de suas características, alcances e limites, apresenta-se a seguir um panorama sumário da arquitetura participativa no país, enfatizando-se os conselhos e as conferências.

Os conselhos são as instituições participativas mais difundidas, podendo-se considerar que se inscreveram de forma irreversível na gestão pública. É relevante distinguir, dos demais, os conselhos de políticas públicas que têm o papel de gestores de fundos em decorrência de legislação federal. Em caráter obrigatório, há os conselhos de saúde, assistência social, direitos da criança e do adolescente, da educação e de habitação de interesse social. Ao lado desses, há outros conselhos de políticas que não são objeto de exigência legal, como os conselhos de direitos e conselhos temáticos e, ainda, os conselhos de programas. ${ }^{35}$

\footnotetext{
${ }^{35}$ Ver Tatagiba (2002) em seu esforço precursor de distinguir analiticamente os diversos tipos de conselhos.
} 
No âmbito federal, sem distinção de tipologias, Moroni (2009) identifica 64 conselhos, dos quais 13 foram criados no governo Lula - colocando em foco novos temas - e outros nove reestruturados no período. ${ }^{36}$ No âmbito estadual, dados de pesquisa do IBGE permitem constatar a expressão dos conselhos, presentes na totalidade dos estados nos casos dos conselhos de saúde, de assistência social, de educação, de direitos da criança e do adolescente e de habitação, que constituem os casos exigidos para repasse de fundos (IBGE, 2013). Mais além, a totalidade dos estados dispõe de conselhos de cultura, meio ambiente, direitos do idoso e segurança alimentar. Em relação a outros conselhos pesquisados, têm-se os seguintes resultados: conselhos de segurança, em $63 \%$ dos estados; de transporte, 48,1\%; de esporte, $63 \%$; de direitos da pessoa com deficiência, 59,3\%; de promoção da igualdade racial, 37\%; e de direitos de lésbicas, gays, bissexuais, travestis e transexuais, 18,5\% do total. Destacam-se, portanto, ao lado dos conselhos de políticas em seus recortes setoriais ou temáticos, os conselhos de direitos de minorias. O levantamento indica que, do universo de conselhos estaduais, o tempo médio de existência é de 16, 7 anos, posteriores, portanto, à CF 1988. A maioria reuniu-se no ano de referência da pesquisa e tem caráter deliberativo, ao passo que a existência de fundos é uma característica relativamente pouco presente.

No âmbito municipal, pesquisas do IBGE permitem notar a expansão e a diversidade dos conselhos, com destaque para a disseminação mais expressiva dos conselhos gestores das políticas sociais requeridos por legislação federal. Conforme dados de 2001, os conselhos de saúde existiam em 98,5\% dos municípios; os de assistência social, em 91,65\%; de educação, em 91,0\%; e de direitos da criança e do adolescente, em 71,7\%. Os conselhos de habitação, à época ainda não requeridos por legislação federal, apresentavam-se em $11 \%$ dos municípios. Em relação às características básicas do seu desenho institucional, a maioria era deliberativa e paritária e tinha funcionamento regular (IBGE, 2001). Quase uma década depois, em 2009, 97,3\% dos municípios dispunham de conselhos municipais de saúde; 98,1\% dispunham de conselhos de educação; e 97,8\%, de conselhos dos direitos da criança e do adolescente (IBGE, 2009). No caso da assistência social, em 2008, 98,8\% dos municípios tinham essa entidade (IBGE, 2008). A expansão do número de conselhos no caso da habitação social é significativa em virtude da legislação aprovada em 2005, de modo que 42,6\% dos municípios apresentavam conselhos de habitação em 2009, e 58,2\%, em 2011 (IBGE, 2009, 2011).

Em 2001, levantamento do IBGE registrava a ocorrência de outros conselhos de políticas não exigidos em legislação nos municípios brasileiros: 34\%, no caso de conselhos de emprego e trabalho; 29\%, de meio ambiente; $22 \%$, de turismo; $13 \%$, de cultura; $6 \%$, de política urbana; e $5 \%$, de transportes. Notava-se ainda a existência de outros conselhos com ocorrências menos expressivas. Observando-se uma tendência geral de expansão do número de conselhos nos diversos campos setoriais, destaca-se o caso dos conselhos de meio ambiente, presentes em 47,6\% dos municípios em 2009 (IBGE, 2001, 2009).

\footnotetext{
${ }^{36}$ Nesse cômputo, há conselhos de políticas, de direitos, de programas e conselhos administrativos. Foram criados os conselhos das cidades, da juventude, da economia solidária, do programa Primeiro Emprego, gestor da internet, de desenvolvimento industrial, de desenvolvimento econômico e industrial, do esporte, e de transparência e combate à corrupção. Reformularam-se os conselhos de recursos hídricos, da Embrapa, do desenvolvimento rural sustentável, da promoção da igualdade racial, da mulher, do combate à discriminação, dos direitos da pessoa portadora de deficiência, e de turismo. Ver, adicionalmente, o site da Secretaria Geral da Presidência (<www.secretariageral.gov.br/art_social/ conselhos-e-conferencias >), que computa entre 2003 e 2010 a criação de 19 conselhos e a reforma de 16 .
} 
Para além da expansão quantitativa de conselhos no ambiente dos municípios brasileiros, ressalta-se também sua diversidade, incluindo-se a criação de conselhos de direitos. Como ilustração, em 2009, os conselhos de direitos humanos foram constatados em 1,4\% do total de municípios; em 2011, os conselhos de direitos da mulher, em 10,7\%; de direitos do idoso, em 51,1\%; de direitos das pessoas com deficiência, em 14,2\%; e de promoção de igualdade racial, em 3,5\% do total (IBGE, 2009, 2011).

O panorama da existência dos conselhos em sua heterogeneidade e diversidade indica um alargamento de temas e objetos das políticas públicas e da participação social. No período posterior à promulgação da CF 1988 e dos novos marcos da legislação, o desafio inicial consistia na criação dessas instituições participativas e de sua consolidação. Atualmente, o desafio para os governos e a sociedade encontra-se em seu aprofundamento democrático, no aprimoramento dessas experiências e em sua maior efetividade, implicando o fortalecimento das capacidades de gestão e governança do Estado bem como dos atores societários.

As conferências nacionais - mecanismo de formulação e orientação de políticas públicas criadas, inicialmente, na década de 1930 - redesenharam-se com o impulso do processo de redemocratização e dos novos marcos legais, sobretudo mediante a incorporação expressiva da sociedade civil. A partir desse contexto, observam-se experiências isoladas no âmbito municipal e, de forma mais evidente, a expansão das conferências nacionais, seja no número de edições, seja no alargamento dos temas que as conformam, indicando uma maior inclusividade política.

Pogrebinschi e Santos (2011) demonstram que as conferências se tornam cada vez mais inclusivas pela sua amplitude e abrangência, em consequência da ampliação dos temas envolvidos, abrangendo crescentemente direitos das minorias e dos segmentos sociais mobilizados. No que toca ao primeiro ponto, os autores indicam que ocorreu uma ampliação de temas e edições de conferências: entre 1998 e 2009, foram realizadas 88 conferências, das quais 55 no período de 2003-2009. ${ }^{37}$ No que se refere ao segundo ponto, incluíram-se temas ligados às minorias, somando um total de 32 , dos quais 22 foram introduzidos no governo Lula.

Em relação ao segundo ponto, as conferências têm envolvido um conjunto cada vez mais heterogêneo de participantes que representam diversos grupos sociais, distribuídos entre organizações não governamentais, movimentos sociais, sindicatos de trabalhadores, entidades empresariais, entre outros (Pogrebinschi \& Santos, 2011; Pogrebinschi, 2012). Na maior parte dos casos, as conferências, nas diversas áreas de políticas e temas, têm incluído todos os estados e um número expressivo de municípios. Conforme indicações da Secretaria Nacional de Articulação Social, no período 20032012, elas mobilizaram, em seu conjunto, mais de 7 milhões de participantes (Brasil, 2014c). Tais tendências sinalizam a consolidação desse desenho participativo, que se mostra inclusivo e que aporta contribuições para o processo de formação de agenda das políticas em foco, ao lado da definição de diretrizes e de um acompanhamento participativo de sua gestão, favorecendo formas de articulação intergovernamental.

\footnotetext{
${ }^{37}$ Ver também, no site da Secretaria Geral da Presidência, o cômputo geral das conferências nacionais (<https:// novoportal.secretariageral.gov.br/participacao-social/conferencias $>$ ), que indica 127 conferências realizadas entre 1941 e 2013, sendo 86 entre 2003 e 2012.
} 
Na discussão empreendida, partiu-se do argumento de que a perspectiva de governança e, em especial, a de governança democrática ou participativa apresenta-se no Brasil de forma distinta dos países centrais, nos quais reemerge como sucedânea das concepções e ideários reformistas na linha da NPM ou como resposta aos déficits democráticos e de coordenação do rol de atores cada vez mais amplo e plural que integra o universo da gestão pública. No caso brasileiro, as propostas, projetos e práticas na trilha da governança participativa emergem em paralelo à disseminação dos ideários reformistas na vertente da NPM e das experiências concretas no âmbito federal e em alguns estados.

De fato, como se indicou, a trilha de governança com viés participacionista - por meio da criação e funcionamento de instituições participativas - resultou em um conjunto heterogêneo, abrangente, de práticas de participação institucionalizada, com desenhos, potenciais e alcances distintos. A tendência de expansão e pluralização dessas experiências, construídas ao longo das últimas décadas, aponta para a consolidação das instituições participativas. Aponta, também, para os desafios de seu aprimoramento em relação aos desenhos, funcionamento e efetividade; para desafios para a própria gestão pública a partir dos processos participativos; e para desafios da participação para os atores governamentais e não governamentais.

\section{Os Desafios da Modernização e Profissionalização da Administração Pública}

A profissionalização da administração pública brasileira tem conhecido importantes avanços desde meados dos anos 1990, que se aprofundam a partir da década passada. Esses avanços podem ser percebidos no crescimento sustentado da representatividade do vínculo estatutário - o que melhor se aproxima do modelo burocrático weberiano, dada a prevalência do recrutamento por concurso na estrutura do emprego público, conforme mostram os dados da Tabela 1.

Tabela 1 - Vínculos celetistas e estatutários na composição do emprego do setor público brasileiro,* em anos selecionados (pessoas)

\begin{tabular}{|l|c|c|c|c|}
\hline \multicolumn{1}{|c|}{ Tipo de vínculo } & 1995 & 2002 & 2009 & 2009/1995 (\%) \\
\hline Celetista permanente & 1.235 .450 & 873.583 & 635.997 & $-48,5$ \\
\hline Estatutário & 4.516 .170 & 4.427 .177 & 6.961 .433 & 57,2 \\
\hline Total & 5.751 .620 & 5.300 .760 & 7.597 .430 & 32,1 \\
\hline
\end{tabular}

*Estão excluídas empresas estatais e entidades públicas autônomas.

Fonte: adaptado de Nogueira \& Cardoso Jr., 2011: 418.

Como se nota, o número de empregados do setor público, considerando celetistas e estatutários cresce em 32,1\% entre os anos de 1995 e 2009. Esse aumento decorre basicamente da expansão do número de estatutários, já que os celetistas apresentam variação negativa no período. Assim, a representatividade dos estatutários nos empregos públicos permanentes - o que exclui as categorias 
de trabalhadores temporários e somente comissionados, além de estagiários - eleva-se de 78,5\% do total, em 1995, para 91,6\% em 2009.

Ao lado da crescente representatividade do emprego estatutário, contudo, observa-se um expressivo quantitativo de trabalhadores, designados por Marconi (2010) como "não estatutário sem carteira assinada", que alcança $21 \%$ do total de empregos na administração pública em 2007, considerando as três esferas de governo. Esse tipo de trabalhador com vínculo empregatício precário deveria desempenhar atividades temporárias, de natureza sazonal ou transitória. No entanto, não é o que ocorre na prática. Conforme pondera Marconi (2010: 233), "ao menos uma parcela dos servidores contratados sob essa forma precária possui um número de anos de serviço elevado", desempenhando atividades de natureza continuada.

Outra variável que indica o maior grau de profissionalização consiste no crescente nível de escolarização dos trabalhadores com vínculo permanente com a administração pública, conforme dados da Tabela 2. Há uma evolução bastante favorável na representatividade dos trabalhadores com nível de escolarização maior que ensino médio, que passa de 27,0\% do total em 1995 para 40,6\% em 2009. A melhoria da escolarização ocorre nos três níveis de governo, com um ganho mais expressivo nos municípios, onde o indicador passa de 15,6\% do total em 1995 para 33,\% em 2009. Ainda assim, são os governos locais aqueles que apresentam a situação mais desfavorável nesse quesito.

Tabela 2 - Participação de trabalhadores com grau de escolaridade maior que ensino médio no setor público brasileiro, * por nível de governo, em anos selecionados (\%)

\begin{tabular}{|l|c|c|c|}
\hline \multicolumn{1}{|c|}{ Esfera de governo } & 1995 & 2002 & 2009 \\
\hline Federal & 46,1 & 38,9 & 49,2 \\
\hline Estadual & 29,7 & 39,7 & 48,3 \\
\hline Municipal & 15,6 & 21,6 & 33,6 \\
\hline Total & 27,0 & 31,1 & 40,6 \\
\hline
\end{tabular}

* Estão excluídas empresas estatais e entidades públicas autônomas.

Fonte: Nogueira \& Cardoso Jr., 2011: 427.

Se os avanços na direção da profissionalização são inegáveis, também o são os desafios que se colocam na trajetória rumo à sua efetiva consolidação. A esse respeito, podem ser relacionados três fatores que atuam para dificultar esforços em busca da materialização desse desiderato político: o custo da construção de burocracias profissionalizadas, no sentido weberiano; o uso indiscriminado de cargos comissionados, de recrutamento amplo; e a herança de arranjos administrativos pretéritos, determinando a coexistência de relações de trabalho e situações de vínculo muito heterogêneas num mesmo órgão ou entidade. São fatores cujos efeitos incidem de forma desigual sobre os diferentes níveis de governo, afetando com maior intensidade os governos subnacionais.

No caso brasileiro, a capacidade de recrutar e reter pessoal, cujo balizamento mais geral é informado pelo orçamento, foi restringida pela citada LRF, que estabeleceu tetos para as despesas com pessoal para os diferentes níveis de governo. E as despesas de pessoal, nos governos subnacionais, já tensionam os limites 
impostos pela legislação, ${ }^{38}$ como mostram os dados da Tabela 3. No caso dos estados, em 2012, tais despesas chegaram a ultrapassar o teto. No caso dos municípios, havia ainda margem para o incremento da participação desse tipo de despesa, até porque o teto legal é superior ao estadual. Vale registrar que a terceirização de mão de obra, muitas vezes apontada como subterfúgio contábil para contornar as restrições da LRF, não pode efetivamente cumprir tal papel, ao ser bloqueada pela própria legislação. ${ }^{39}$

Tabela 3 - Participação das despesas com pessoal e limites da LRF, nos governos subnacionais, em 2012 (\%)

\begin{tabular}{|l|c|c|}
\hline \multicolumn{1}{|c|}{ Tipo de despesa } & Municípios & Estados \\
\hline Pessoal & 44,2 & 49,7 \\
\hline Limite da LRF & 54,0 & 49,0 \\
\hline
\end{tabular}

Fonte: adaptado de Khair, 2013.

Essa restrição imposta pela LRF assume contornos mais problemáticos quando se considera a necessidade de suprir os déficits de capacidade de atuação na prestação de serviços à população, em especial na área social, cuja responsabilidade vem sendo progressivamente assumida pelos níveis subnacionais de governo, como discutido anteriormente. Vale dizer, há uma pressão latente para ampliar quadros técnicos e administrativos e, por extensão, os gastos com pessoal, que praticamente não encontra espaço orçamentário para sua viabilização.

No tocante aos cargos comissionados, estes têm sido usualmente apontados pela literatura como um dos principais óbices à profissionalização da administração pública brasileira (Abrucio, 1993). Formalmente destinado a preenchimento das funções de direção e de assessoramento especializado, o cargo em comissão é de livre nomeação do governante. Esse aspecto - a livre nomeação - abre espaço para sua utilização de forma indiscriminada, notadamente na esfera local de governo, o que se insinua na expressividade de sua participação na estrutura do emprego público. De acordo com dados do IBGE (2012), os ocupantes de cargo em comissão - representados por funcionários sem vínculo permanente com o setor público, nomeados apenas para a função - correspondiam a 3,4\% do total de empregos públicos estaduais, em 2012, enquanto nos municípios alcançavam nada menos que $8,4 \%$ do correspondente total de empregos públicos.

A expressividade dos cargos em comissão indica sua utilização para funções que extravasam a alta direção e o assessoramento especializado, estendendo-se a cargos "que descem a níveis bastante baixos na estrutura" da administração pública (Pacheco, 2010: 287). Trata-se de nomeações de caráter político, que colidem com os supostos da burocracia weberiana em dois aspectos principais, ainda que não restritos aos mesmos. Um deles, mais evidente, tem a ver com a forma de recrutamento, que prescinde do concurso ou qualquer forma de avaliação competitiva de competências e habilidades

${ }^{38}$ Ainda que o limite imposto para despesas com pessoal do governo federal - da ordem de $40,9 \%$ da RCL - seja menor que os dos governos estaduais e municipais, os gastos com pessoal no Executivo federal, em 2012, ficaram em torno de $23 \%$ do total, ou seja, bem abaixo do permitido pela LRF.

${ }^{39} \mathrm{~A}$ LRF determina que os valores dos contratos com terceirização de mão de obra, que tenha correspondência com categorias funcionais abrangidas pelo plano de cargos do quadro de pessoal do órgão ou entidade, sejam contabilizados, para fins de enquadramento no limite legal, como despesa de pessoal. 
concernentes ao cargo a ser preenchido. O outro se refere à natureza transitória do desempenho da função, gerando descontinuidades administrativas e gerenciais, ao dificultar a preservação da memória institucional e cercear o aprendizado advindo da experiência.

Por fim, as decisões dos gestores públicos relativas à contratação de pessoal passam comumente ao largo da preocupação de estruturar um aparato administrativo de conformação burocrática, composto por corpos permanentes lastreados na ideia de carreira como princípio geral da organização da função pública. De um lado, há o reconhecimento, por parte da literatura, de que a administração pública brasileira "foi constituída a partir de cargos e não de carreiras" (Costa, 2011: 82), cuja estrutura, quando existente, nem sempre é definida de forma consistente (Nogueira \& Cardoso Jr., 2011). Como observa Loureiro (1998), a definição mais usual de carreira abrange um conjunto de cargos e funções hierarquicamente definidos, com a possibilidade de avanço vertical em torno de mais de um cargo. Tal concepção, contudo, revela-se mais exceção que regra no país, cujas carreiras tendem a ser formadas por "cargos isolados ou planos gerais que constituem meras agrupações de cargos" (Nogueira \& Cardoso Jr., 2011: 425). De outro lado, prevalecem o imediatismo e a adoção de soluções tópicas na gestão de recursos humanos, em detrimento de um planejamento institucional de longo prazo (Nogueira \& Cardoso Jr., 2011), o que se expressa na criação casuística de carreiras e cargos (Carvalho, 2011), da qual não escapa sequer o governo federal. Tem-se, em consequência, uma situação caracterizada pela existência de uma multiplicidade de "cargos e carreiras, sem um eixo norteador que os vincule entre si e estabeleça critérios hierárquicos mais consistentes" (Carvalho, 2011: 142). A título de ilustração, levantamento feito por Carvalho (2011: 141) registra a existência, em 2010, de nada menos " 129 carreiras e 22 planos especiais de cargos (...), além de cargos isolados" no âmbito do governo federal. A esse quadro se soma a adoção de expedientes variados, como a cessão de pessoal entre órgãos e mesmo governos e a contratação irregular de trabalhadores temporários, entre outros, tornando ainda mais complexo o gerenciamento de pessoal.

Análise realizada por Costa (2011), relativa ao Ministério da Saúde (MS), ilustra bem a questão. Somente em 2005, após mais de duas décadas, houve a retomada da realização de concursos no MS, o que é atribuído, pela autora, à pressão do Ministério Público do Trabalho (MPT), em face de irregularidades na contratação de trabalhadores, mais especificamente, a expressiva parcela de funções ocupadas por terceirizados e detentores de contratos temporários de trabalho. ${ }^{40} \mathrm{Na}$ sede do MS, responsável pela formulação e gestão da política setorial, apenas 31\% do quadro de pessoal era, à época, formado por servidores efetivos, recrutados por meio de concurso; participação que se eleva para $57 \%$ do total em 2011. Os servidores efetivos do MS, por sua vez, distribuíam-se em diversos planos de carreiras e em planos especiais de cargos, incluindo o Plano Geral de Cargos do Poder Executivo (PGPE) ${ }^{41}$ e o Plano de Classificação de Cargos (PCC). ${ }^{42}$

\footnotetext{
${ }^{40}$ Nesse ano, os profissionais terceirizados, com contratos temporários com a União e consultores contratados com a intermediação de organismos internacionais no MS somavam 9.762 pessoas (Costa, 2011).

${ }^{41}$ Criado pela lei n. 11.357/2006, o PGPE é composto por cargos efetivos de nível superior, médio e auxiliar que não integram carreiras específicas, planos especiais de cargos ou planos de carreiras instituídos por leis específicas.

${ }^{42}$ O PCC foi estabelecido pela lei n. 5.645/1970, com o propósito de enquadrar a totalidade do pessoal civil (Carvalho: 2011), agrupando os servidores públicos em classes, que posteriormente adquiriram características de carreira. Segundo Costa (2011), o PCC absorvia, em 2005, cerca de 65 mil servidores do MS.
} 
O movimento na direção da profissionalização da administração pública, cuja face mais visível é a crescente institucionalização da realização de concursos como forma de recrutamento de servidores nos diferentes níveis de governo, aparenta ser um caminho de difícil reversão na realidade brasileira. Essa mesma adesão à realização de concursos serve também para lançar luz sobre os limites do processo, notadamente na esfera local de governo. De fato, os concursos que vêm ocorrendo nos municípios não refletem necessariamente uma decisão autônoma do gestor local, decorrendo, em diversas circunstâncias, de ações administrativas ou judiciais movidas por organismos de fiscalização e controle externo, como o MPT e os Tribunais de Contas. Além disso, os processos de seleção utilizados nem sempre são abertos e universais, assumindo apenas caráter interno, por meio dos quais se busca efetivar funcionários sem vínculos permanentes da administração municipal. A persistência do recurso à contratação irregular atestada pela expressividade dos trabalhadores sem vínculo permanente ${ }^{43} \mathrm{com}$ a administração pública, da ordem de $27,6 \%$ do total do emprego municipal em 2012 - refletindo "o imediatismo e o casuísmo da mentalidade do gestor público" (Nogueira \& Cardoso Jr., 2011: 437) no tocante à contratação de pessoal, mostra as dificuldades com as quais o concurso ainda se defronta.

A despeito da inegável relevância desse tipo de restrição, a fragilidade financeira da administração pública, em especial nas esferas dos governos estadual e municipal, emerge como a principal dificuldade que se interpõe à profissionalização, na medida que assume caráter estrutural. De fato, não se vislumbram perspectivas favoráveis de ampliações significativas da capacidade de financiamento do setor público descoladas do crescimento da economia, até porque a carga tributária já alcançou patamar elevado, situando-se próximo à média dos países da OCDE (Khair, 2013), que apresentam, regra geral, renda per capita superior à brasileira. Trata-se de uma restrição que assume contornos mais críticos em face da baixa qualidade da oferta de serviços públicos, em especial nas áreas que respondem às necessidades mais imediatas da população - saúde, educação, segurança pública, proteção social etc. - a qual não tem como ser enfrentada apenas com melhorias na qualificação dos servidores, demandando também ampliação da capacidade de oferta e, por extensão, do quadro de servidores.

As principais perspectivas de avanços na profissionalização da administração pública brasileira recaem na esfera federal que, historicamente, detém as condições institucionais e financeiras mais confluentes com a construção de uma burocracia consoante as premissas weberianas. Esse processo deve abarcar um conjunto ampliado de funções no âmbito das atividades do núcleo estratégico ou exclusivas do Estado. O que se tem em mente aqui é a assunção de novas atribuições relacionadas às atividades de formulação e gestão de políticas públicas e de regulação econômica e social, demandando profissionais com qualificação técnica para lidar com as mesmas, como, por exemplo, profissionais com formação na área de engenharia. Nos níveis subnacionais de governo, em especial no nível local, a pressão pela expansão e melhoria na prestação de serviços públicos tende a levar ao crescimento do número de servidores, criando dificuldades financeiras no tocante ao recrutamento de profissionais mais qualificados ou à realização de investimentos na qualificação dos servidores já contratados. Assim, avanços no sentido da profissionalização devem assumir caráter mais circunscrito que no governo federal, com uma maior seletividade na definição do que se considera estratégico para fins de construção de capacidade burocrática informada pelas premissas do modelo weberiano.

\footnotetext{
${ }^{43}$ Inclui trabalhadores temporários e somente comissionados, além de uma pequena parcela de estagiários.
} 


\section{Considerações Finais}

A administração pública brasileira vem passando por transformações de grande magnitude desde a última década do século XX e que se aprofundam no decorrer do século XXI. São transformações que envolvem tanto as funções que o setor público desempenha quanto a forma como este se organiza para desempenhá-las, ou seja, suas dimensões funcional e organizacional. Ainda que o processo de mudanças guarde similaridades com iniciativas reformistas desenvolvidas no plano internacional, ele apresenta traços que são peculiares ao país, seja no tocante às motivações para as inovações introduzidas, seja no tocante à sua implementação e aos resultados alcançados.

No que se refere às mudanças ocorridas nas funções desempenhadas pelo Estado brasileiro, embora a análise empreendida não tenha se dedicado explicitamente à sua discussão, restaram evidenciadas três questões principais. A primeira diz respeito ao alargamento da prestação de serviços na área social, impulsionado, em larga medida, pela definição de direitos sociais, de recorte universalizado, no âmbito da CF 1988, cuja observância vem sendo crescentemente incorporada à agenda pública. A segunda está relacionada à inflexão, iniciada no primeiro governo Lula, na agenda política neoliberal prevalecente até o segundo governo Fernando Henrique Cardoso, trazendo de volta a percepção de que o Estado tem um papel importante na promoção do desenvolvimento econômico e social, que não pode ser simplesmente delegada ao mercado. A terceira remete ao rol ampliado de funções de natureza regulatória, advindas tanto da retroação do intervencionismo estatal na economia, refletindo as iniciativas de privatização, em especial na área de infraestrutura econômica, quanto das transformações estruturais da própria economia e da sociedade como um todo, intensificadas pela acelerada incorporação de novas tecnologias e pelo fenômeno da globalização.

Já no tocante às transformações na estrutura organizacional do setor público e seus mecanismos de atuação, a análise colocou em relevo três processos principais. O primeiro aglutina-se em torno do movimento de delegação da execução de um conjunto diversificado de serviços públicos, inscritos no rol de atividades não exclusivas do Estado, a organizações da sociedade civil ou da iniciativa privada. Como visto, trata-se de um movimento cujo protagonismo recai nos governos subnacionais e que é movido por razões que avançam além da justificativa de obtenção de ganhos de eficiência, usualmente citada na literatura, como a preocupação em contornar a necessidade de expansão do aparato da administração pública e a busca de alternativas para lidar com restrições na capacidade de financiamento da realização de investimentos via orçamento. Dele resultam novos arranjos organizacionais, tipificados pelas OSs, Oscips e PPPs, que vêm se somar às modalidades de terceirização e parceria convencionalmente adotadas pela administração pública brasileira. O segundo remete à descentralização intergovernamental, com a crescente execução da prestação de serviços na área social pelos governos locais, conferindo materialidade a diretrizes descentralizantes do texto constitucional. O processo é comandado e induzido pelo governo federal, cabendo aos governos estaduais, grosso modo, uma atuação complementar e subsidiária à dos governos locais. Do processo advém um redesenho profundo da estrutura do emprego público no país, que se torna majoritariamente local. O terceiro e último processo condensa as iniciativas de aprofundamento democrático no desenvolvimento das atividades de governo, em sintonia, também aqui, com diretrizes do texto constitucional. 
São iniciativas confluentes com a ideia de governança democrática, da qual emerge uma pluralidade de instituições participativas, notadamente na esfera local de governo, que mediatizam o envolvimento da sociedade na implementação das políticas públicas, favorecendo sua capacidade de influir nas decisões relativas à definição da agenda pública e, principalmente, de monitorar e avaliar sua execução.

Desses processos reformistas emergem novos padrões de relações internas no Estado e entre ele, o mercado e a sociedade civil, conformando uma arquitetura organizacional de crescente complexidade. Isso demanda novas formas de coordenação, integração e controle das atividades do setor público, reafirmando a importância da construção de burocracias meritocráticas e dotadas de expertise pública como condição primária e indispensável para a ampliação da capacidade de atuação do Estado. Reside aqui o principal desafio com o qual se defronta a administração pública brasileira do período contemporâneo.

A profissionalização da administração pública começou a ser ensaiada no país, como visto, nos anos 1930. Manteve-se, contudo, como um processo em aberto, no sentido de parcial ou inconcluso, sendo reafirmada, como um desiderato político, e relançada pela CF 1988. A despeito dos inegáveis avanços que vêm sendo observados desde então, na direção da construção de uma burocracia profissionalizada, há, ainda, um longo e difícil caminho a percorrer. Uma das principais dificuldades que emergem nesse percurso diz respeito ao movimento de descentralização. De fato, o emprego público vem se concentrando nos níveis subnacionais de governo, com destaque para os governos locais, que apresentam, reconhecidamente, menor capacidade de recrutar e reter profissionais para as atividades mais exigentes de qualificação técnica e conhecimento especializado. Outra dificuldade refere-se à persistência de práticas de contratação de pessoal que passam ao largo de critérios de impessoalidade e meritocracia, da qual não escapa sequer o governo federal. Por fim, cabe mencionar o legado das políticas adotadas na área de recursos humanos nas diferentes esferas de governo, que implica formas muito variadas de classificação, remuneração e gratificação para os servidores públicos, de gerenciamento complexo, constituindo um obstáculo a mais para o aprimoramento e a modernização da gestão pública.

Por sua vez, o aprimoramento e a modernização da gestão pública brasileira não podem prescindir do protagonismo do governo federal, com iniciativas consistentes de apoio à construção de capacidade administrativa nos níveis subnacionais de governo. De certa forma, o Programa Nacional de Apoio à Modernização da Gestão e do Planejamento dos Estados e do Distrito Federal (Pnage) e o Programa de Modernização do Controle Externo dos Estados e Municípios (Promoex), ambos lançados pelo governo Lula, são iniciativas que denotam o reconhecimento da importância da cooperação, no plano federativo, para enfrentar déficits de aparelhamento burocrático na implementação de políticas e no atendimento às demandas e necessidades dos cidadãos. Sem entrar no mérito dos resultados de tais programas, até porque sequer discutidos, cabe observar que, sem a definição de uma agenda consistente em prol da reforma da gestão pública, com uma perspectiva de longo prazo, capaz de galvanizar o interesse e o compromisso dos diferentes níveis de governo em torno de sua execução, dificilmente o Brasil levará a termo a profissionalização de sua burocracia. Trata-se de empreendimento que nada tem de trivial, tendo em vista, em particular, as características muito heterogêneas do federalismo no país. 


\section{Referências}

ABRUCIO, F. L. Profissionalização do serviço público federal. In: ANDRADE, R. C. \& JACCOUD, D. (Orgs.). Estrutura e Organização do Poder Executivo. Brasília: Enap/SAF, 1993.

ABRUCIO, F. L. Para além da descentralização: os desafios da coordenação federativa no Brasil. In: FLEURY, S. (Org.). Democracia, Descentralização e Desenvolvimento: Brasil e Espanha. Rio de Janeiro: FGV, 2006.

ABRUCIO, F. L.; PEDROTI, P. \& PÓ, M. V. A formação da burocracia brasileira: a trajetória e o significado das reformas administrativas. In: LOUREIRO, M. R.; ABRÚCIO, F. L. \& PACHECO, R. S. (Orgs.). Burocracia e Política no Brasil: desafios para o Estado democrático no século XXI. Rio de Janeiro: FGV, 2010.

AFFONSO, R. \& SILVA, P. L. B. Descentralização e Políticas Sociais. São Paulo: Fundap, 1996.

ARRETCHE, M. Mitos da descentralização: mais democracia e eficiência nas políticas públicas. Revista Brasileira de Ciências Sociais, 11(31): 44-67, 1996.

ARRETCHE, M. Estado Federativo e Políticas Sociais: determinantes da descentralização. Rio de Janeiro, São Paulo: Revan, Fapesp, 2000.

ARRETCHE, M. Democracia, Federalismo e Centralização no Brasil. Rio de Janeiro: Editora FGV, Editora Fiocruz, 2012.

ARRETCHE, M. (Coord.). Capacidades Administrativas dos Municípios Brasileiros para a Política Habitacional. Brasília: Ministério das Cidades, Secretaria Nacional de Habitação, 2013.

BELSITO, B. G. \& VIANA, F. B. O limite de comprometimento da receita corrente líquida em contratos de parceria público-privada. Revista do BNDES, 39: 123-160, 2013.

BERAMENDI, P. Federalism. In: BOIX, C. \& STOKES, S. C. (Eds.). The Oxford Handbook of Comparative Politics. New York: Oxford University Press, 2009.

BLÖNDAL, J. R. International Experience Using Outsourcing, Public-Private Partnerships, and Vouchers. Washington: IBM Center for the Business of Government, 2005.

BOURGON, J. Finalidade pública, autoridade governamental e poder coletivo. Revista do Serviço Público, 61(1): 5-34, 2010.

BRASIL. Ministério da Administração e Reforma do Estado. Plano Diretor da Reforma do Aparelho do Estado. Brasília: Mare, 1995.

BRASIL. Senado Federal. Constituição da República Federativa do Brasil. Brasília: Saraiva, 2006.

BRASIL. Ministério do Planejamento, Orçamento e Gestão. Secretaria de Gestão. Relações de Parceria entre Poder Público e Entes de Cooperação e Colaboração no Brasil. Brasília: MPOG, Seges, 2010.

BRASIL. Constituição dos Estados Unidos do Brasil [1946]. Disponível em: http://presrepublica.jusbrasil.com. br/legislacao/92058/constituicao-d. Acesso: 6 mar. 2014a.

BRASIL. Controladoria-Geral da União. Secretaria Federal de Controle Interno. Termos de Parceria firmados pelo Ministério da Justiça com Oscips entre os exercícios de 2008 a 2011. Relatório de Auditoria Especial n. 00190.009683/2011-31. Disponível em: <http://sistemas2.cgu.gov.br/relats/uploads/5728_\%20Termos\%20 de\%20Parceria\%20-\%20MJ.pdf>. Acesso em: 13 mar. 2014b.

BRASIL. Secretaria Geral da Presidência. Participação Social no Brasil: entre conquistas e desafios. Brasília: Secretaria Geral da Presidência da República, 2014c. Disponível em: <https://novoportal.secretariageral.gov. br/participacao-social>. Acesso em: 8 de ago. 2014.

BRASIL, F. P. D. \& CARNEIRO, R. Os caminhos (e descaminhos) de democratização das políticas urbanas: o que há de novo no Brasil contemporâneo? Cadernos Gestão Pública e Cidadania, 55: 11-42, 2010. 
BRESSER-PEREIRA, L. C. Da administração pública burocrática à gerencial. Revista do Serviço Público, 47(1):128, 1996.

BRITO, B. M. B. \& SILVEIRA, A. H. P. Parceria público-privada: compreendendo o modelo brasileiro. Revista do Serviço Público, 56(1): 7-21, 2005.

CARNEIRO, R. \& MENICUCCI, T. M. G. Gestão Pública no século XXI: as reformas pendentes. Brasília, IPEA, 2011. (Texto para Discussão n. 1.686).

CARVALHO, E. D. C. Emprego público e ocupações no serviço público municipal nos anos 2000. In: CARDOSO JR., J. C. (Org.). Burocracia e Ocupação no Setor Público Brasileiro. Rio de Janeiro, Ipea, 2011.

CHRISTENSEN, T. \& LAEGREID, P. The whole-of-government approach to public sector reform. Public Administration Review, 67(6): 1.059-1.066, 2007.

CHRISTENSEN, T. \& LAEGREID, P. Governance and administrative reforms. In: LEVI-FAUR, D. (Ed.). The Oxford Handbook of Governance. Oxford: Oxford University Press, 2012.

COMISSÃO DAS COMUNIDADES EUROPEIAS. Livro Verde sobre as Parcerias Público-Privadas e o Direito Comunitário em Matéria de Contratos Públicos e Concessões. Bruxelas: CCE, 2004.

CORTES, S. M. V. Fóruns participativos e governança: uma sistematização das contribuições da literatura. In: LUBAMBO, C.; COELHO, D. B. \& MELO, M. A. (Orgs.). Desenho Institucional e Participação Política: experiência no Brasil contemporâneo. Petrópolis: Vozes, 2005.

COSTA, L. A. Insulamento Burocrático, Autonomia do Estado e Inserção Social: um estudo do Ministério da Saúde na coordenação nacional do SUS, 2011. Tese de Doutorado, Belo Horizonte: Faculdade de Sociologia e Ciências Humanas, Universidade Federal de Minas Gerais.

DI PIETRO, M. S. Z. Parcerias na Administração Pública: concessão, permissão, franquia, terceirização e outras formas. São Paulo: Atlas, 1997.

DUNLEAVY, P. \& HOOD, C. From old public administration to new public management. Public Money and Management, 14(3): 9-16, 1994.

DUNLEAVY, P. et al. New Public Management is dead: long live digital-era governance. Journal of Public Administration Research and Theory, 16: 467-493, 2005.

FISHER, F. Participatory governance: from theory to practice. In: LEVI-FAUR, D. (Ed.). The Oxford Handbook of Governance. Oxford: Oxford University Press, 2012.

FUNG, A. Associations and democracy: between theories, hopes and realities. Annual Review of Sociology, 29: 515-539, 2003.

FUNG, A. \& WRIGHT, E. O. Deepening democracy: institutional innovations in empowered participatory governance. Politics and Science, 29(1): 5-41, 2001.

GOHN, M. G. Os conselhos municipais e a gestão urbana. In: SANTOS JÚNIOR, O.; RIBEIRO, L. C. \& AZEVEDO, S. (Orgs.). Governança Democrática e Poder Local. Rio de Janeiro: Revan, 2004.

HOOD, C. A public management for all seasons? Public Administration, 69(1): 3-19, 1991.

HOOD, C. The New Public Management in the 1980s: variations on a theme. Accounting, Organizations and Society, 20(2/3): 93-109, 1995.

HOOD, C. \& PETERS, G. The middle aging of New Public Management: into the Age of Paradox. Journal of Public Administration Research and Theory, 14(3): 267-282, 2004.

INSTITUTO BRASILEIRO DE GEOGRAFIA E ESTATÍSTICA (IBGE). Perfil dos Municípios Brasileiros 2001. Rio de Janeiro: IBGE, 2001. 
INSTITUTO BRASILEIRO DE GEOGRAFIA E ESTATÍSTICA (IBGE). Perfil dos Municípios Brasileiros 2008. Rio de Janeiro: IBGE, 2008.

INSTITUTO BRASILEIRO DE GEOGRAFIA E ESTATÍSTICA (IBGE). Perfil dos Municípios Brasileiros 2009. Rio de Janeiro: IBGE, 2009.

INSTITUTO BRASILEIRO DE GEOGRAFIA E ESTATÍSTICA (IBGE). Perfil dos Municípios Brasileiros 2011. Rio de Janeiro: IBGE, 2011.

INSTITUTO BRASILEIRO DE GEOGRAFIA E ESTATÍSTICA (IBGE). Perfil dos Municípios Brasileiros 2012. Rio de Janeiro: IBGE, 2012.

INSTITUTO BRASILEIRO DE GEOGRAFIA E ESTATÍSTICA (IBGE). Perfil de Informações Básicas Estaduais 2012. Rio de Janeiro: IBGE, 2013.

KETTL, D. F. A revolução global: reforma da administração do setor público. In: BRESSER-PEREIRA, L. C. \& SPINK, P. (Orgs.). Reforma do Estado e Administração Pública Gerencial. Rio de Janeiro: Editora FGV, 2005.

KHAIR, A. A Questão Fiscal e o Papel do Estado. São Paulo: Fundação Perseu Abramo, 2013.

KLINJ, E. H. New public management and governance. In: LEVI-FAUR, D. (Ed.). The Oxford Handbook of Governance. Oxford: Oxford University Press, 2012.

LEVI-FAUR, D. From government to big governance. In: LEVI-FAUR, D. (Ed.). The Oxford Handbook of Governance. Oxford: Oxford University Press, 2012.

LIMA JR., O. B. As reformas administrativas no Brasil: modelos, sucessos e fracassos. Revista do Serviço Público, 2, ano 49: 5-30,1998.

LOPEZ, F. G. \& BARONE, L. As Entidades sem Fins Lucrativos e as Políticas Públicas Federais: tipologia e análise de convênios e organizações (2003-2011). Brasília: Ipea, 2013. (Texto para Discussão n. 1.896)

LOPEZ, F. G. \& BUENO, N. S. Transferências Federais a Entidades Privadas sem Fins Lucrativos (1999-2010). Rio de Janeiro: Ipea, 2012. (Texto para Discussão 1.778)

LOUREIRO, M. R. Radiografia da alta burocracia federal brasileira: o caso do Ministério da Fazenda. Revista do Serviço Público, 4, ano 49: 47-83, 1998.

LYNN JR., L. E. Public management: a concise history of the field. In: LYNN JR., L. E. \& POLLITT, C. (Eds.). The Oxford Handbook of Public Management. Oxford: Oxford University Press, 2007.

LYNN JR., L. E. The many faces of governance: adaptation? Transformation? Both? Neither? In: LEVI-FAUR, D. (Ed.). The Oxford Handbook of Governance. Oxford: Oxford University Press, 2012.

MANNING, N. et al. Reformas de Gestão Pública: o que a América Latina tem a aprender com a OCDE? In: MEDEIROS, P. C. \& LEVY, E. (Orgs.). Novos Caminhos da Gestão Pública: olhares e dilemas. Rio de Janeiro, Brasília: Qualitymark, Consad, 2009.

MARCH, J. G. \& OLSEN, J. P. Rediscovering Institutions: the organizational basis of politics. New York: Free Press, 1989.

MARCONI, N. Uma radiografia do emprego público no Brasil: análise e sugestões de políticas. In: LOUREIRO, M. R.; ABRÚCIO, F. L. \& PACHECO, R. S. (Orgs.). Burocracia e Política no Brasil: desafios para o Estado democrático no século XXI. Rio de Janeiro: FGV, 2010.

MORONI, J. A. O direito à participação no governo Lula. In: AVRITZER, L. (Org.). Experiências Nacionais de Participação Social. São Paulo: Cortez, 2009.

NOGUEIRA, R. P. \& CARDOSO JR., J. C. Tendências e problemas da ocupação do setor público brasileiro: conclusões parciais e recomendações de pesquisa. In: CARDOSO JR., J. C. (Org.). Burocracia e Ocupação no Setor Público Brasileiro. Rio de Janeiro: Ipea, 2011. 
NUNES, E. A Gramática Política no Brasil: clientelismo e insulamento burocrático. Rio de Janeiro, Brasília: Jorge Zahar, Enap, 1997.

PPP BRASIL: O OBSERVATÓRIO DAS PARCERIAS PÚBICO-PRIVADAS. Procedimento de manifestação de interesse nos Estados: relatório sobre projetos de PPP em fase de estruturação via PMI, 2012. Disponível em: $<$ http://pppbrasil.com.br/portal/content/ppp-brasil-divulga-relatorio-sobre-os-pmis-nos-estados-0 >. Acesso em: 25 fev. 2014.

OLIVEIRA, F. A. Fundef e Saúde: duas experiências (virtuosas?) de descentralização. In: REZENDE, F. \& OLIVEIRA, F. A. (Orgs.). Descentralização e Federalismo Fiscal no Brasil: desafios da reforma tributária. Rio de Janeiro: Konrad Adenauer Stiftung, 2003.

OLIVEIRA, F. A. Política Econômica, Estagnação e Crise Mundial: Brasil, 1980-2010. Rio de Janeiro: Beco do Azougue, 2012.

PACHECO, R. S. A agenda da nova gestão pública. In: LOUREIRO, M. R.; ABRÚCIO, F. L. \& PACHECO, R. S. (Orgs.). Burocracia e Política no Brasil: desafios para o Estado democrático no século XXI. Rio de Janeiro: FGV, 2010.

PEREIRA, L. D. A gestão da força de trabalho em saúde na década de 90. Physis - Revista de Saúde Coletiva, 14(2): 363-382, 2004.

PESSOA, E. Estado, serviços públicos e emprego público no Brasil: principais tendências nos anos 90. In: ENCONTRO NACIONAL DE ECONOMIA POLÍTICA, VIII, 2003, Florianópolis.

PETERS, B. Guy. Governance as political theory. In: LEVI-FAUR, D. (Ed.). The Oxford Handbook of Governance. Oxford: Oxford University Press, 2012.

PIERRE, J. New Governance, New Democracy? Gothenburg: University of Gothenburg, mar. 2009. (QOG Working Paper Series 4)

PIRES, D. Reestruturação Produtiva e Trabalho em Saúde no Brasil. São Paulo: Annablume, 2008.

POLLITT, C. Decentralization. In: FERLIE, E.; LYNN JR., L. E. \& POLLITT, C. (Eds.). The Oxford Handbook of Public Management. Oxford: The Oxford University Press, 2007.

POLLITT, C. \& BOUCKAERT, G. Avaliando reformas da gestão pública: uma perspectiva internacional. Revista do Serviço Público, 53(3): 5-30, 2002.

POLLITT, C. \& BOUCKAERT, G. Public Management Reform: a comparative analysis. New York: Oxford University Press, 2004.

POGREBINSCHI, T. Conferências Nacionais de Políticas Públicas para Grupos Minoritários. Rio de Janeiro: Ipea, 2012. (Texto para discussão n.1.741)

POGREBINSCHI, T. \& SANTOS, F. Participação como representação: o impacto das conferências nacionais de políticas públicas no Congresso. Dados - Revista de Ciências Sociais, 54(3): 259-305, 2011.

PRZEWORSKI, A. O Estado e o cidadão. In: BRESSER-PEREIRA, L. C.; WILHEIN, J. \& SOLA, L. (Orgs.). Sociedade e Estado em Transformação. São Paulo: Editora Unesp, 1999.

RAICHELIS, R. Intervenção profissional do assistente social e as condições de trabalho no Suas. Serviço Social \& Sociedade, 104: 750-772, 2010.

REZENDE, F. C. As reformas e as transformações no papel do Estado: o Brasil em perspectiva comparada. In: ABRUCIO, F. L. \& LOUREIRO, M. R. (Orgs.). O Estado numa Era de Reformas: os anos FHC - Parte 1. Brasília: MP, Seges, 2002.

SKELCHER, C. Public-Private Partnerships and hybridity. In: FERLIE, E.; LYNN JR., L. E. \& POLLITT, C. (Eds.). The Oxford Handbook of Public Management. Oxford: The Oxford University Press, 2007. 
SMITH, S. R. NGOs and contracting. In: FERLIE, E.; LYNN JR., L. E. \& POLLITT, C. (Eds.). The Oxford Handbook of Public Management. Oxford: The Oxford University Press, 2007.

SOUZA, C. Federalismo, desenho constitucional e instituições federativas no Brasil pós-1988. Revista Sociologia Política, 24: 105-121, 2005.

STOKER, G. Governance as theory: five propositions. International Social Science Journal, 50(1.555): 17-28, 1998.

TATAGIBA, L. Conselhos gestores e a burocratização das políticas públicas no Brasil. In: DAGNINO, E. (Org.). Sociedade Civil e Participação Social no Poder Local. Rio de Janeiro: Paz e Terra, 2002.

TORRES, M. D. F. Agências, Contratos e Oscips: a experiência brasileira. Rio de Janeiro: FGV, 2007.

TOURINHO, R. A atuação do Ministério Público do Trabalho no combate a terceirização do sistema carcerário no Brasil. Revista Eletrônica de Direito Administrativo Econômico (Redae), 13: 1-10, 2008.

TRIBUNAL DE CONTAS DA UNIÃO (TCU). Acórdão 3.025/2010: plenário. Relatório de levantamento. Fiscalis 814/2010. Avaliação da estrutura de recursos humanos voltada para a análise da prestação de contas de transferências voluntárias da União. Disponível em: <www.lexml.gov.br/urn/urn:lex:br:tribunal.contas.uniao ;plenario:acordao:2010-11-10;3025 > . Acesso em: 12 fev. 2014a.

TRIBUNAL DE CONTAS DA UNIÃO (TCU). Relatório de Auditoria Operacional: TC 018.739/2012-1. Transferência do gerenciamento de serviços públicos de saúde a organizações sociais. Falhas. Determinações e recomendações. Monitoramento. Disponível em: <www.jusbrasil.com.br/diarios/62587424/dou-secao-1-05-12-2013-pg-326>. Acesso em: 4 mar. 2014b.

VINCENT, A. Theories of State. Cambridge: Blackwell Publishers, 1987.

WAMPLER, B. Instituições participativas como enxertos na estrutura do Estado: a importância de contextos, atores e estratégias. In: PIRES, R. R. C. (Org.). Efetividade das Instituições Participativas no Brasil. Brasilia: Ipea, 2011.

WILLIANSON, O. E. Transaction-cost economics: the governance of contractual relations. Journal of Law and Economics, 22(2): 233-261, 1979. 